\title{
Keiretsu and relationship-specific investment: Implications for market-opening trade policy
}

\author{
by \\ Larry D. Qiu \\ Hong Kong University of Science and Technology \\ and \\ Barbara J. Spencer* \\ University of British Columbia and the NBER
}

Final version is published in the

Journal of International Economics, 58/1, October 2002, 49-79.

This paper considers the implications of relationship-specific investment within keiretsu for policies aimed at opening the Japanese market for intermediate goods, such as auto parts. Both VIEs applied to parts and VERs restricting Japanese exports of autos cause the keiretsu to import a wider range of parts, but of a relatively unimportant type, such as seat covers. Since keiretsu investment and output fall, the total value of U.S. parts exports may actually fall. For a given value of these exports, a VIE is less costly for U.S. consumers and Japanese producers, but a VER is preferred by U.S. automakers.

JEL Classification: F12; F13; L13; L14

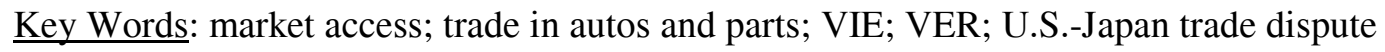

\footnotetext{
* This paper has benefited from presentation at Columbia University (Economics Department), New York University (Economics Department) and at the University of British Columbia (Faculty of Commerce). We thank the participants and also an anonymous referee for many helpful suggestions and comments. Financial support was provided by the Social Sciences and Humanities Research Council of Canada. An earlier version of this paper was titled, "Keiretsu and Relational Quasi Rents: Implications for VIEs and VERs".

* Please address correspondence to Barbara J. Spencer, Faculty of Commerce, University of British Columbia, 2053 Main Mall, Vancouver BC, V6N 3A4, Canada. Phone (604)822-8479; Fax (604)822-8477; e-mail, barbara.spencer@commerce.ubc.ca.
} 


\section{Keiretsu and relationship-specific investment: Implications for market-opening trade policy}

\section{Introduction}

It is well known that Japanese tariff rates on manufactured goods are lower than rates for most other industrialized countries, but that Japan imports significantly less. This has lead to complaints, particularly in the United States, that Japan has very high non-tariff barriers. Since visible and formal non-tariff barriers such as quotas are not evident, one focus of complaint has been that typical Japanese corporate groups, referred to as keiretsu ${ }^{1}$, have acted as a barrier to imports ${ }^{2}$. These complaints have received some support from empirical studies that find lower imports in industries with a high keiretsu presence ${ }^{3}$. In response, policy makers in the United States, have put pressure on Japan to open its markets to meet quantitative targets such as VIEs (voluntary import expansions) in which a country is forced to agree to a given market share or total value for imports of particular products. Prominent targeted products include semiconductors and auto-parts ${ }^{4}$.

Despite these measures to ensure greater access to the Japanese market, it is debatable whether keiretsu constitutes an "unfair" barrier to trade. In particular, the long-term supply arrangements within vertical keiretsu have been defended as a means of raising efficiency due to gains from relationship-specific investments by keiretsu suppliers ${ }^{5}$. These are investments directed at making a product more valuable to a

\footnotetext{
${ }^{1}$ This would include auto producers such as Toyota and Nissan.

${ }^{2}$ For example, according to Church (1995), the keiretsu "do business mainly with each other, freezing out competing buyers and sellers, both foreign and domestic. This system forms the very fabric of the way the Japanese do business, and it does more than outright trade barriers or even government administrative guidance' to keep out foreign products. Especially, it seems, U.S. auto parts ...such as shock absorbers, mufflers, tailpipes and disk-brake pads...sell for less than half to only a third the price of made-in-Japan parts of comparable quality. What then limits American parts to around $1.5 \%$ of the Japanese market? The keiretsu system, Americans conclude".

${ }^{3}$ Examples include Lawrence (1991) and Fung (1991), but Saxonhouse (1989) has an opposing view.

${ }^{4}$ In the 1991 semiconductor pact, the U.S. demanded a 20\% market-share target. The 1995 agreement on Japanese autos and parts demanded (among other things) that Japan's automakers increase annual purchases of parts from the U.S. by $\$ 9$ billion in three years (Bernier, et al., 1995, p.16).

${ }^{5}$ McMillan (1996) argues persuasively that the favoring of keiretsu suppliers in contract renewals helps solve the "holdup problem" so as to provide appropriate incentives for these investments, which are financed by the supplier with no guarantee that costs will be covered by the subsequent sale of parts.
} 
particular buyer (in this case, the keiretsu automaker), but not to other potential buyers. There are a number of possible examples ${ }^{6}$, but most important for our purposes are investments in modifications that improve the fit or ease of assembly with other parts produced by the keiretsu, but which are not relevant to the particular production processes of other auto manufacturers.

Using the auto-industry as an example, Spencer and Qiu (2001) model the effects of relationshipspecific investments ${ }^{7}$ by suppliers within a vertical keiretsu on the ability of U.S. auto-parts producers to access the Japanese market. By raising efficiency, these investments increase the range of parts produced in the keiretsu at the expense of imports. However, the rents that these investments create are not easily observable outside the keiretsu and Spencer and Qiu (2001) argue that this, combined with some counterintuitive responses of imports, could create a strong impression of a trade barrier. Thus, even if keiretsu do not "unfairly" block access to the Japanese market, attempts by the U.S. to impose market opening policies may nevertheless be understood as a natural response to the perception of a trade barrier.

In the present paper, we build on Spencer and Qiu (2001) to develop the implications of relationshipspecific investments for various policies aimed at opening the Japanese market for intermediate goods, such as auto- parts. We consider three types of VIEs. The simplest, referred to as a 'content VIE', requires that autos produced in Japan achieve at least some specified U.S. content per auto. We also consider a 'marketshare VIE', which forces Japan to meet a market-share target for imported parts, as well as a 'total-value VIE', which requires that Japan import a given total value of U.S. parts. Since there is a continuum of parts, with parts ordered in terms of their contribution to the total cost of an auto, referred to as their 'cost-share', we can address the effects of policy on the range of imported parts as well as on their overall value. In line with U.S. complaints, Spencer and Qiu (2001) argue that keiretsu would tend to import those parts that are

\footnotetext{
${ }^{6}$ Another example might involve investment by suppliers in "just in time" delivery, such as locating close to the automaker's plant or cooperating with other suppliers to coordinate delivery. For applications within keiretsu, see Aoki (1988; pp 216-218) and Dyer and Ouchi (1993, p 55).

${ }^{7}$ Also see McLaren (1999), who argues that less formal bargaining arrangements can dominate formal contracts in encouraging cooperative investments.
} 
least important for production ${ }^{8}$. A natural question is then whether a VIE would be met by the import of just a few additional parts, each making a large contribution to the target because of a high cost-share, or if instead, rather more parts would be imported, but with the parts continuing to be of the more peripheral type. There is some indication that the latter was the case with respect to the 1992 U.S.-Japan auto agreement ${ }^{9}$ and, consistent with this, we show that for all three types of VIEs, additional imports would be in the order determined by increasing cost-shares, with lower cost parts first. Higher cost-shares increase the returns from relationship-specific investments, making the automaker more reluctant to replace these parts with imports.

Generally a VIE reduces relationship-specific investment, raising the keiretsu cost of production, which leads to a reduction in Japanese auto output and hence to a reduction in the total Japanese demand for parts. Thus although the U.S. share of the Japanese parts' market rises due to the import of a greater range of parts, it is possible that a content or market-share VIE would be self defeating in the sense that the total value of U.S. parts exported to Japan would fall. For the same reason, it may not be feasible for Japan to achieve a specified increase in the total value of its parts imports, particularly if the demanded increase is large ${ }^{10}$. However, if Japan imports no or very few parts at free trade, which could arise due to a high productivity of relationship-specific investment, then U.S. parts exports would rise.

Consideration is also given to the effects of a VER (voluntary export restraint ${ }^{11}$ ) and an import tariff which limit U.S. imports of autos from Japan. As we show, these policies can have significant effects in

${ }^{8}$ For example, Rubenstein (1990, p8) observes that "American suppliers primarily provide Japanese carmakers with bulky, low-value, low-skill products such as carpets, glass, tires, exhaust systems, and audioequipment. High-value, highly-skilled components such as engines, transaxles, suspension systems, and brakes are made for Japanese carmakers by Japanese-owned suppliers." See also Aoki (1988, pp 208-209) and Dyer and Ouchi (1993, Fig 1, p.52).

${ }^{9}$ For example, in response to the 1992 agreement on autos, "initially simple mechanical parts and such items as carpets and aluminium were purchased, rather than more technologically complicated parts like electronic controls and engines" (see McMillan, 1996).

${ }^{10}$ This may partly explain the $\$ 0.6$ billion shortfall in meeting the $1994 \$ 3.6$ billion target for U.S. exports of auto parts to Japan, which was part of the 1992 auto-parts agreement with President Bush. As stated in the New York Times (July 14, 1995), Japanese imports fell short because production of vehicles in Japan declined, leading all of Japan's top five automakers to miss their targets for the import of parts.

${ }^{11}$ The VER acts as an import quota in which the Japanese manufacturer of autos gains the quota rents. 
opening the Japanese market for auto-parts. This result may initially appear surprising because in standard models, a restriction in final-good output would reduce the demand for both domestically produced and imported parts. However, in the current framework, the reduced output of Japanese autos makes it less profitable for keiretsu suppliers to undertake relationship-specific investments. This leads to an increase in the range of imported parts and hence raises the U.S. share of the Japanese parts market.

The effects of a VER or tariff are particularly relevant since these policies have been extensively applied against the Japanese auto industry, including being used as threats to gain agreement for a VIE in auto parts ${ }^{12}$. A main result is then to show that a credible threat of a VER (or tariff) giving rise to the same total value of U.S. parts exports as a VIE applied to parts would always be sufficient to induce the Japanese automaker to comply with the VIE ${ }^{13}$. This follows because the VER causes a greater reduction in keiretsu investment and output. This raises the price of autos and if the aim is to achieve a given target value of U.S. parts exports, U.S. consumers as well as the keiretsu would prefer the VIE. Nevertheless, U.S. profit from auto production is higher under the VER and since the gain in profit can more than offset the consumer loss, we find that the U.S. is not necessarily better off using a VIE than a VER as a policy to expand parts exports.

Managed trade in general and VIEs in particular are strongly opposed by many economists. In 1993, more than 50 economists sent a letter to President Clinton and Prime Minister Hosokawa asking the two leaders to reject the demands for managed trade ${ }^{14}$. However, significant support for the idea from policy makers has lead to considerable interest in research on the topic. Bhagwati (1987) is among the first to criticize VIEs and much of the literature, including Greaney (1996), Krishna et al. (1998) and as well as the

\footnotetext{
${ }^{12}$ In the 1995 U.S./Japan auto-dispute, Japan was threatened with prohibitively high tariffs on Japanese luxury automobiles if it did not agree to market-share targets in its auto parts industry (see Levinsohn, 1997). Also, VERs have been extensively applied to autos, including by the U.S. in May 1981.

${ }^{13}$ In a model with Cournot competition between a U.S. and Japanese parts' supplier, Krishna and Morgan (1998) show that the threat of a sufficiently high tariff on autos can induce the U.S. firm to increase exports to comply with a market-share target, but a tariff on its own causes a decease in the export of parts.

${ }^{14}$ As explained in the letter (see FEER, 1993, p26), the "principal factor underlying such demands for managed trade has been the crude and simplistic view that Japan is importing too few manufactures owing to 'structural barriers' which make Japan 'special'."
} 
current paper, show that, by raising the price of the product concerned, market-share VIEs tend to be anticompetitive $^{15}$. Bjorksten (1994) considers both VIEs and VERs and shows that in a Kreps-Scheinkman duopoly model with price competition and capacity constraints, a VER has similar effects as under Cournot competition, leading to a reduction in profits by the exporting firm as in the present paper. However, as shown by Krishna (1989), this outcome tends to be reversed under Bertrand competition. Also, Cronshaw and Markusen (1995) consider the implications of hidden trade barriers for policy in a simple, but useful, asymmetric information framework, but they do not directly model the effects of VIEs or VERs. The current paper differs from all this literature because of its explicit consideration of the effects of keiretsu.

The rest of the paper is organized as follows. Section 2 lays out the model and develops the main effects of the keiretsu under free trade. Section 3 then considers the types of parts that will be imported in response to a VIE and also the implications for the total value of parts imports. Next, Section 4 concerns the use of a VER or tariff applied to final-good exports as a market-opening policy with respect to the import of parts. Comparisons are then made as to the magnitude of the effects of the VIE versus the VER or tariff, leading to some welfare implications. Finally, section 5 contains concluding remarks.

\section{The investment model}

This section sets out the model for the base case in which there is free trade. Additional justification and explanation of the model can be found in Spencer and Qiu (2001).

\subsection{Relationship-specific investment and cost of production}

A final good, such as an auto, is produced in both Japan and the United States based on Cournot competition between a Japanese firm, referred to as a J-maker and a U.S. firm referred to as an A-maker. The $\mathrm{J}$ and A makers produce homogeneous outputs, denoted $\mathrm{y}^{\mathrm{J}}$ and $\mathrm{y}^{\mathrm{A}}$ respectively. Our basic results also apply to the case in which the J-maker has a world monopoly, but the extension to oligopoly seems appropriate given the institutional reality of oligopolistic competition between U.S. and Japanese auto producers and the

\footnotetext{
${ }^{15}$ There are some exceptions, particularly when the policy applies to an intermediate good (see Krishna and Morgan, 1998 and Krishna et al., 2001).
} 
importance of U.S. production in motivating U.S. trade policy. In order to consider the effects of U.S. import restrictions applied against Japanese autos, we make the convenient assumption that autos are all sold in the U.S. at a price $\mathrm{P}=\mathrm{P}(\mathrm{Y})$ where $\mathrm{Y}=\mathrm{y}^{\mathrm{J}}+\mathrm{y}^{\mathrm{A}}$.

The J-maker and its long-term suppliers in Japan, referred to as J-suppliers, are assumed to form a keiretsu ${ }^{16}$ in which J-suppliers potentially engage in relationship-specific investments of value to the J-maker, but not to the A-maker. Suppliers in the U.S., referred to as A-suppliers, produce parts for the A-maker and potentially also export these parts to be used by the J-maker, but they operate based on short-term contracts under pure competition ${ }^{17}$ and hence do not make relationship-specific investments. The assumption that Asuppliers do not make relationship-specific investments of value to the J-maker captures the institutional reality that the long-term suppliers of parts for Japanese production of autos are overwhelmingly Japanese ${ }^{18}$.

Rather than unfair exclusion, we would argue that this is most likely due to the severe difficulties faced by non-Japanese firms in gaining access to the flow of technical and other keiretsu information necessary for suitable design of parts in coordination with other keiretsu suppliers ${ }^{19}$. In addition to a knowledge of Japanese language and customs, access to this information requires mutual trust, which first involves the development of a good business relationship, perhaps as a simple manufacturer of outsourced

\footnotetext{
${ }^{16}$ Our analysis applies to top ranked (or first-tier) firms with technological expertise and long-term supply relationships and not to the more marginal firms that may be used as short term capacity buffers so as to help maintain permanent employment in the core manufacturer (see Asanuma, 1989, pp 16-18 and Aoki, 1988, pp 208-209). Keiretsu are very stable. For instance, " member firms of Kyohokai, an association formed by Toyota parts suppliers, numbered 171 in 1984. Of these firms, 153 had been continual members of Kyohokai during the 11 years since 1973" (see Asanuma, 1989, p. 5).

${ }^{17}$ A large number of establishments produce auto-parts in the U.S., for example, 4856 in 1992 (Office of Automotive Affairs) and the average length of contract was only 2.5 years in 1989, up from 1.3 years in 1984 (see Dyer and Ouchi, 1993).
}

${ }^{18}$ See Dodwell Marketing Consultants (1990), which lists the main auto-parts suppliers in Japan. Levinsohn (1997, p18) estimates that the U.S. share of sales of parts to Japanese automakers in Japan is only about $1 \%$.

${ }^{19}$ Branstetter (2000) documents the importance of the flow of technical information within keiretsu. 
parts sold to Japanese assemblers in the supplier's home country ${ }^{20}$. Proximity also facilitates the exchange of information and due to this and other advantages, such as the ease of "just in time" delivery, actual production in Japan may be necessary if U.S. firms are to become long-term keiretsu suppliers within Japan ${ }^{21}$. Since any such production does not form part of U.S. exports to Japan (and is currently small), it would not change our basic results concerning the effects of trade policy on the volume and pattern of U.S. exports of parts to $\mathrm{Japan}^{22}$. As for the lack of relationship-specific investment with respect to the A-maker, this highlights the institutional differences across countries, but is mainly for simplicity of the model ${ }^{23}$.

In modelling investment within the keiretsu, a central role is played by the fact that parts differ with respect to their costs of production and hence their importance for downstream costs. Assuming constant returns to scale in production and letting $\mathrm{c}^{\mathrm{i}}$ and $\mathrm{c}^{* \mathrm{i}}$ denote the respective marginal (and average) costs of production of part $\mathrm{i}$ in Japan and the U.S., we arrange auto parts in order of increasing average cost of

\footnotetext{
${ }^{20}$ For example, Tenneco made agreements with Unisia-Jecs Corp (a keiretsu supplier to Nissan) and with Futuba (a keiretsu supplier to Toyota) to produce parts (such as shock absorbers) designed by its Japanese partners for sale to Japanese plants in the U.S.. This increased confidence in Tenneco's expertise and now Tenneco hopes to supply Japanese automakers in Japan (see Automotive News, April 27, 1998). Rauch (2002) provides an excellent survey emphasising the importance of business and social networks in facilitating trade due to informational advantages and trust.

${ }^{21}$ In addition to alliances with keiretsu suppliers, the importance of location in Japan for the ability to sell parts in Japan is emphasised by Levinsohn (1997, p18). An example is TRW (a U.S. firm), which initially engaged in joint ventures with Japanese firms supplying the U.S. plants of Toyota and Nissan and then began supplying these firms back in Japan, but only by producing most of these parts in Japan. Also, there is evidence that Japanese suppliers tend to follow a main keiretsu assembler in setting up production facilities in other countries, but in addition, parts are often imported from Japan (see for example, Belderbos and Sleuwagen, 1998 and Head et al., 1995). This supports the idea that a presence in Japan is important for gaining access to the information flow within keiretsu, but once the benefits are realized, parts incorporating relationship-specific investments can then be exported to keiretsu assemblers or produced locally in a host country. Suppliers producing just in the U.S. (or Europe) would be at an informational disadvantage.
}

\footnotetext{
${ }^{22} \mathrm{An}$ interesting possibility suggested by a referee is that a U.S. VIE might put pressure on the J-maker to more easily accept U.S. suppliers into the keiretsu, which (in future work) might be modelled as a reduction in the J-maker's bargaining power, making it more profitable for these suppliers to undertake investments. Because of the importance of access to information from keiretsu suppliers in Japan, this analysis would require consideration of U.S. foreign direct investment as well as exports to Japan.

${ }^{23}$ A more complicated model could be developed with symmetric institutions in which the A and $\mathbf{J}$ suppliers make relationship-specific investments of value to the A and J-maker's respectively, but this would not change the pattern of trade with Japan or the main insights with respect to trade policy.
} 
production. This ordering is assumed to be the same in both countries. Exploiting the fact that the number of parts, $\mathrm{N}$, is large, it proves convenient to express marginal costs as differentiable and increasing functions, $\mathrm{c}^{\mathrm{i}}=\mathrm{c}(\mathrm{i})$ and $\mathrm{c}^{* \mathrm{i}}=\mathrm{c} *(\mathrm{i})$ on the interval $\mathrm{i} \in[0, \mathrm{~N}]$. The production of an auto requires parts and labor to be combined in fixed proportion and without loss of generality, we set the units of output of each part i so that each auto is produced using just one part of each type. For the keiretsu, the importance of part i for downstream costs is then captured by the cost-share, $\sigma^{\mathrm{i}}\left(\sigma\right.$ is Greek s for share), defined as $\sigma^{\mathrm{i}}=\sigma(\mathrm{i}) \equiv$ $\mathrm{c}(\mathrm{i}) / \mathrm{C}(\mathrm{N})$ for $\mathrm{C}(\mathrm{N}) \equiv \int_{0} \mathrm{~N} c(\mathrm{i}) \mathrm{di}$, where the ordering of parts ensures $\sigma^{\prime}(\mathrm{i})>0$. In order to focus on the export of parts to Japan, we assume that parts can be produced more cheaply in the U.S.. Since we also assume (for simplicity) that $\mathrm{c}^{\mathrm{i}}=\mathrm{c}(\mathrm{i})$ and $\mathrm{c}^{* \mathrm{i}}=\mathrm{c}^{*}(\mathrm{i})$ are linear in $\mathrm{i}$ with equal slopes, it follows that the efficiency gap, denoted $\delta \equiv \mathrm{c}^{\mathrm{i}}-\mathrm{c}^{* \mathrm{i}} \geq 0$ between Japan and the U.S. is constant ${ }^{24}$.

For each part i, a J-supplier, namely supplier i, potentially makes a relationship-specific investment, denoted $\mathrm{k}^{\mathrm{i}}$. This creates rent for the J-maker (but not the A-maker) in the form of a reduction in the cost of the process of assembly for each auto using the part from supplier i. For example, the investment might improve the fit of part $\mathrm{i}$ with the other parts that the J-maker uses to produce autos. The magnitude, denoted $\mathrm{r}^{\mathrm{i}}$, of the rent created per auto, is assumed to be proportional to the initial value, denoted $\mathrm{w}^{\mathrm{o}}$, of the cost of the assembly process per auto in the absence of relationship-specific investments and also to the relative contribution of part i to cost, as measured by the cost-share, $\sigma(i)$. This last condition reflects the idea that the greater the proportion of costs associated with the part, the greater the potential for cost reduction. For example, a given amount of investment is likely to be more effective in reducing costs when it applies to engines rather than to seat covers. Also, using the cost-share has the reasonable feature that the level of rent is invariant to an inflation in the costs of all parts.

Consequently, letting $\theta$ denote the productivity of investment, we assume

$$
\mathrm{r}^{\mathrm{i}}=\mathrm{w}^{\mathrm{o}} \sigma(\mathrm{i}) \theta \mathrm{h}\left(\mathrm{k}^{\mathrm{i}}\right) \text { for } 0<\theta \leq \theta^{\max },
$$

where $\theta^{\max } \equiv \min \left\{1, \mathrm{C}(\mathrm{N}) / \mathrm{w}^{\mathrm{o}}\right\}$ and $\mathrm{h}\left(\mathrm{k}^{\mathrm{i}}\right)$ satisfies:

\footnotetext{
${ }^{24}$ These assumptions can be relaxed as in Spencer and Qiu (2001) to allow for some parts to be produced at lower cost in Japan and also to allow for $\delta$ to depend on i with $\delta^{\prime}(i) \leq 0$.
} 


$$
\mathrm{h}(0)=0, \mathrm{~h}^{\prime}\left(\mathrm{k}^{\mathrm{i}}\right)>0, \mathrm{~h}^{\prime \prime}\left(\mathrm{k}^{\mathrm{i}}\right)<0 \text { and } \mathrm{h}\left(\mathrm{k}^{\mathrm{i}}\right)<1 .
$$

From (1) and (2), higher levels of investment create more rent for the J-maker, but at a decreasing rate ${ }^{25}$. Also, the restrictions on the magnitude of the rent, due to $\theta \leq \theta^{\max }$ and $\mathrm{h}\left(\mathrm{k}^{\mathrm{i}}\right)<1$, ensure that there is no "free lunch" from assembly or from the production and use of keiretsu parts ${ }^{26}$.

Letting $p^{i}$ represent the price paid to supplier $i$, the J-maker's marginal cost for part $i$ is given by $\gamma^{i}$ $\equiv \mathrm{p}^{\mathrm{i}}-\mathrm{r}^{\mathrm{i}}$ if the part is purchased from within the keiretsu and by $\mathrm{c}^{* \mathrm{i}}$ if the part is imported. The J-maker's overall marginal cost, denoted $\gamma$, is then equal to the total cost of parts plus $w^{0}$. In the U.S., the A-maker obtains each part from the A-suppliers at a price $\mathrm{c}^{*_{\mathrm{i}}}$, giving rise to a marginal cost, denoted by $\gamma^{*}$, which we assume to be constant. The J-maker, supplier i and the A-maker respectively earn profits:

$$
\pi^{\mathrm{J}}=\mathrm{y}^{\mathrm{J}}(\mathrm{P}(\mathrm{Y})-\boldsymbol{\gamma}), \phi^{\mathrm{i}}=\mathrm{y}^{\mathrm{J}}\left(\mathrm{p}^{\mathrm{i}}-\mathrm{c}^{\mathrm{i}}\right)-\mathrm{k}^{\mathrm{i}} \text { and } \pi^{\mathrm{A}}=\mathrm{y}^{\mathrm{A}}\left(\mathrm{P}(\mathrm{Y})-\boldsymbol{\gamma}^{*}\right)
$$

\subsection{Order of moves and bargaining over parts' prices}

An important aspect of relationship-specific investment is that it is sunk prior to purchase of the part and the supplier cannot be guaranteed a return based on a contract that is conditional on the amount of investment. This is due to the difficulty of actually observing $\mathrm{k}^{\mathrm{i}}$, which would include non observable costs, such as the costs of obtaining the information and coordination with other suppliers. Consequently, as in Spencer and Qiu (2001), we assume that the investment, $\mathrm{k}^{\mathrm{i}}$, is sunk prior to bargaining over the price, $\mathrm{p}^{\mathrm{i}}$, with the J-maker and also that $\mathrm{p}^{\mathrm{i}}$ can be based on the rent, $\mathrm{r}^{\mathrm{i}}$, but not $\mathrm{k}^{\mathrm{i}}$.

In the free trade setting, the order of moves is as follows. At stage 1, each supplier i commits to its investment $\mathrm{k}^{\mathrm{i}} \geq 0$, and simultaneously, the $\mathrm{J}$-maker and A-maker both specify their respective outputs, $\mathrm{y}^{\mathrm{J}}$ and $\mathrm{y}^{\mathrm{A}}$. Since each firm sets its choice variable to maximize own profit taking the other choice variables as given, this gives rise to a Nash equilibrium in $\mathrm{k}^{\mathrm{i}}, \mathrm{y}^{\mathrm{J}}$ and $\mathrm{y}^{\mathrm{A}}$. Anticipating the outcome of the stage 2 bargaining process over the prices, $\mathrm{p}^{\mathrm{i}}$, the two automakers are assumed to earn strictly positive profits, but for some Jsuppliers, investment at stage 1 could cause a loss. If $\phi^{\mathrm{i}}<0$ for all $\mathrm{k}^{\mathrm{i}} \geq 0$ or if supplier $\mathrm{i}$ anticipates that

\footnotetext{
${ }^{25}$ i.e. $\partial \mathrm{r}^{\mathrm{i}} / \partial \mathrm{k}^{\mathrm{i}}=\mathrm{w}^{0} \sigma(\mathrm{i}) \theta \mathrm{h}^{\prime}\left(\mathrm{k}^{\mathrm{i}}\right)>0$ and $\partial^{2} \mathrm{r}^{\mathrm{i}} /\left(\partial \mathrm{k}^{\mathrm{i}}\right)^{2}=\mathrm{w}^{\mathrm{o}} \sigma(\mathrm{i}) \theta \mathrm{h}^{\prime \prime}\left(\mathrm{k}^{\mathrm{i}}\right)<0$.

${ }^{26}$ These conditions imply $\mathrm{r}^{\mathrm{i}}<\sigma^{\mathrm{i}} \mathrm{C}(\mathrm{N})=\mathrm{c}^{\mathrm{i}}$ and $\mathrm{r}^{\mathrm{i}}<\mathrm{w}^{\mathrm{o}} \sigma(\mathrm{i})$, which implies $\mathrm{w}^{\mathrm{J}} \equiv \mathrm{w}^{\mathrm{o}}-\int_{0}^{\mathrm{N}} \mathrm{r}^{\mathrm{i}} \mathrm{di}>0$.
} 
bargaining would break down at stage 2 , then supplier i sets $\mathrm{k}^{\mathrm{i}}=0$ and exits the market. At stage 2 , the $\mathrm{J}$ maker engages in simultaneous Nash bargaining over the price of part $i$ with each remaining supplier. If an agreement is reached with supplier $\mathrm{i}$, the J-maker orders the $\mathrm{y}^{\mathrm{J}}$ parts needed to produce output $\mathrm{y}^{\mathrm{J}}$. Otherwise, the J-maker imports the part from the lower cost U.S. producers.

Considering stage 2 first, in bargaining with supplier i, the J-maker aims to minimize its marginal cost, $\gamma^{\mathrm{i}}=\mathrm{p}^{\mathrm{i}}-\mathrm{r}^{\mathrm{i}}$, due to part $\mathrm{i}$, with a disagreement or 'threat point' of importing the part at a price, $\mathrm{c}^{* \mathrm{i}}$, if bargaining breaks down. Thus for the Nash bargaining problem, the J-maker can be viewed as maximizing its payoff from agreement, as represented by $y^{\mathrm{J}}\left(\mathrm{c}^{* \mathrm{i}}-\gamma^{\mathrm{i}}\right)$, where $\mathrm{y}^{\mathrm{J}}$ is given from stage 1 . Correspondingly, since investment, $\mathrm{k}^{\mathrm{i}}$, is sunk, supplier i maximizes its variable profit, $\mathrm{y}^{\mathrm{J}}\left(\mathrm{p}^{\mathrm{i}}-\mathrm{c}^{\mathrm{i}}\right)$, with a threat point of no production and zero variable profit. Letting $\alpha \in[0,1)$ represent the bargaining power of the J-maker and 1- $\alpha$ the bargaining power of each supplier, it follows ${ }^{27}$, using $\gamma^{\mathrm{i}}=\mathrm{p}^{\mathrm{i}}-\mathrm{r}^{\mathrm{i}}$ and $\delta=\mathrm{c}^{\mathrm{i}}-\mathrm{c}^{* \mathrm{i}}$, that at the Nash bargaining equilibrium,

$$
\mathrm{p}^{\mathrm{i}}-\mathrm{c}^{\mathrm{i}}=(1-\alpha)\left(\mathrm{r}^{\mathrm{i}}-\delta\right) \text { and } \gamma^{\mathrm{i}}=\mathrm{c}^{* \mathrm{i}}-\alpha\left(\mathrm{r}^{\mathrm{i}}-\delta\right)>0 \text {. }
$$

From (4) and $\alpha<1$, supplier i gains a share, $1-\alpha>0$, of the net rent, $\mathrm{r}^{\mathrm{i}}-\delta$, that it creates due to relationshipspecific investment. We assume $\alpha<1$, since otherwise there is no incentive for investment. The J-maker's share, $\alpha$, of net rent is reflected in a reduction in the marginal cost, $\gamma^{\mathrm{i}}$, of part i below the cost $\mathrm{c}^{* \mathrm{i}}$ of an imported part, but $\gamma^{\mathrm{i}}$ remains strictly positive. The respective payoffs to the J-maker and supplier i (relative to the disagreement point $)$ are: $\mathrm{y}^{\mathrm{J}}\left(\mathrm{c}^{* \mathrm{i}}-\gamma^{\mathrm{i}}\right)=\mathrm{y}^{\mathrm{J}} \alpha\left(\mathrm{r}^{\mathrm{i}}-\delta\right)$ and $\phi^{\mathrm{i}}+\mathrm{k}^{\mathrm{i}}=\mathrm{y}^{\mathrm{J}}(1-\alpha)\left(\mathrm{r}^{\mathrm{i}}-\delta\right)$. It follows that once $\mathrm{k}^{\mathrm{i}}$ is sunk, agreement would be reached for supplier i to produce the part if and only if the rent created from investment is sufficiently large to make $\mathrm{r}^{\mathrm{i}}-\delta \geq 0$. This requires that supplier i set $\mathrm{k}^{\mathrm{i}}>0$, which from (3) and (4) implies a stage 2 profit for supplier i, given by

$$
\phi^{\mathrm{i}}=\mathrm{y}^{\mathrm{J}}(1-\alpha)\left(\mathrm{r}^{\mathrm{i}}-\delta\right)-\mathrm{k}^{\mathrm{i}} \text { if } \mathrm{r}^{\mathrm{i}}-\delta \geq 0 ; \quad \phi^{\mathrm{i}}=-\mathrm{k}^{\mathrm{i}} \text { if } \mathrm{r}^{\mathrm{i}}-\delta<0 .
$$

\subsection{Stage 1: Relationship-specific investments and output}

At the Cournot-Nash equilibrium at stage 1, the $\mathrm{J}$ and A-makers set their outputs and J-suppliers

\footnotetext{
${ }^{27}$ Setting $p^{i}$ to maximize $G^{i} \equiv\left(c^{* i}-\gamma^{i}\right)^{\alpha}\left(p^{i}-c^{i}\right)^{1-\alpha} y^{J}$, we obtain $d \ln G^{i} / d p^{i}=(1-\alpha) /\left(p^{i}-c^{i}\right)-\alpha /\left(c^{* i}-\gamma^{i}\right)=0$. Using $\mathrm{c}^{\mathrm{i}}-\mathrm{r}^{\mathrm{i}}>0$ in (4), we obtain $\gamma^{\mathrm{i}}=(1-\alpha) \mathrm{c}^{* \mathrm{i}}+\alpha\left(\mathrm{c}^{\mathrm{i}}-\mathrm{r}^{\mathrm{i}}\right)>0$.
} 
simultaneously set their investment levels to maximize their respective profits. Considering investment decisions first, at stage 1, supplier i determines the optimal value of $\mathrm{k}^{\mathrm{i}}$ in the event that it would produce the part by maximizing $\phi^{\mathrm{i}}$ as in (5), taking $\mathrm{y}^{\mathrm{J}}, \mathrm{y}^{\mathrm{A}}$ and the investments $\mathrm{k}^{\mathrm{j}}$ for $\mathrm{j} \neq \mathrm{i}$ of the other suppliers as given ${ }^{28}$. Using $\mathrm{r}^{\mathrm{i}}=\mathrm{w}^{\mathrm{o}} \sigma^{\mathrm{i}} \theta \mathrm{h}\left(\mathrm{k}^{\mathrm{i}}\right)$, this gives rise to the Kuhn-Tucker first order conditions ${ }^{29}$ :

$$
\partial \phi^{\mathrm{i}} / \partial \mathrm{k}^{\mathrm{i}}=\mathrm{y}^{\mathrm{J}}(1-\alpha) \mathrm{w}^{\mathrm{o}} \sigma^{\mathrm{i}} \theta \mathrm{h}^{\prime}\left(\mathrm{k}^{\mathrm{i}}\right)-1 \leq 0 \text { and }\left(\partial \phi^{\mathrm{i}} / \partial \mathrm{k}^{\mathrm{i}}\right) \mathrm{k}^{\mathrm{i}}=0,
$$

which define $\mathrm{k}^{\mathrm{i}}=\mathrm{k}\left(\sigma^{\mathrm{i}}, \mathrm{y}^{\mathrm{J}}\right)$ where $\partial \phi^{\mathrm{i}} / \partial \mathrm{k}^{\mathrm{i}}=0$ if $\mathrm{k}^{\mathrm{i}}>0$ and $\mathrm{k}^{\mathrm{i}}=0$ if $\partial \phi^{\mathrm{i}} / \partial \mathrm{k}^{\mathrm{i}}<0$ (parameters $\theta$ and $\alpha$ are omitted for convenience). However, even if $\mathrm{k}^{\mathrm{i}}>0$ from (6), it is possible that revenue (due to $\mathrm{r}^{\mathrm{i}}-\delta \geq 0$ ) would not be sufficient to cover $\mathrm{k}^{\mathrm{i}}$ and hence would lead to a loss. In this case supplier $\mathrm{i}$ would set $\mathrm{k}^{\mathrm{i}}=0$ and not produce the part. Setting $\mathrm{k}^{\mathrm{i}}=\mathrm{k}\left(\sigma^{\mathrm{i}}, \mathrm{y}^{\mathrm{J}}\right)$ in (5) it follows that with free trade in parts, supplier i would produce the part if and only if $\phi^{\mathrm{i}} \geq 0$.

From the ordering of parts from low to high cost-shares, investment, $\mathrm{k}^{\mathrm{i}}$, and rent, $\mathrm{r}^{\mathrm{i}}$, are increasing in $\mathrm{i}$ for $\mathrm{k}^{\mathrm{i}}>0$ (see (A2) of the Appendix). Supposing that suppliers $\mathrm{i}$ and $\mathrm{j}$ for $\mathrm{i}>\mathrm{j}$ make the same level of investment, then since $\sigma^{\mathrm{i}}>\sigma^{\mathrm{j}}$, part i generates a higher level of rent, which is partly captured by each supplier based on the share 1- $\alpha$. This translates into a higher incentive to invest with the result that $\mathrm{k}^{\mathrm{i}}>\mathrm{k}^{\mathrm{j}}$ and $\phi^{\mathrm{i}}>$ $\phi^{\mathrm{j}}$. Thus from (5), using $\partial \phi^{\mathrm{i}} / \partial \mathrm{k}^{\mathrm{i}}=0$ and $\partial \mathrm{r}^{\mathrm{i}} / \partial \sigma^{\mathrm{i}}=\mathrm{r}^{\mathrm{i}} / \sigma^{\mathrm{i}}$, we obtain:

$$
\mathrm{d} \phi^{\mathrm{i}} / \mathrm{di}=\mathrm{y}^{\mathrm{J}}(1-\alpha) \mathrm{r}^{\mathrm{i}} \sigma^{\prime}(\mathrm{i}) / \sigma(\mathrm{i})>0 \text { for } \mathrm{k}^{\mathrm{i}}>0 .
$$

Expressing $\phi^{\mathrm{i}}=\phi\left(\mathrm{i}, \mathrm{y}^{\mathrm{J}} ; \theta\right)$ at the stage 1 equilibrium and supposing that part $\mathrm{i}=\mathrm{T}$ ( $\mathrm{T}$ for trade) satisfies

$$
\phi^{\mathrm{T}}=\phi\left(\mathrm{T}, \mathrm{y}^{\mathrm{J}} ; \theta\right)=\mathrm{y}^{\mathrm{J}}(1-\alpha)\left(\mathrm{r}^{\mathrm{T}}-\delta\right)-\mathrm{k}\left(\sigma^{\mathrm{T}}, \mathrm{y}^{\mathrm{J}} ; \theta\right)=0,
$$

it then follows that $\mathrm{T}$ represents the marginal or lowest cost-share part produced by the keiretsu. If $\phi^{0}=$ $\phi\left(0, \mathrm{y}^{\mathrm{J}} ; \theta\right) \geq 0$, then all parts are produced in the keiretsu ${ }^{30}$.

As illustrated in Fig. 1, parts i with equal or higher cost-shares (i.e. for $\mathrm{i} \geq \mathrm{T}$ ) are produced within the keiretsu and parts $\mathrm{i}$ with lower cost -shares (i.e. for $\mathrm{i}<\mathrm{T}$ ) are imported. Production and investment take

\footnotetext{
${ }^{28}$ The investments $\mathrm{k}^{\mathrm{j}}$ for $\mathrm{j} \neq \mathrm{i}$ and output $\mathrm{y}^{\mathrm{A}}$ influence $\mathrm{k}^{\mathrm{i}}$ only through their effects on $\mathrm{y}^{\mathrm{J}}$.

${ }^{29}$ For $\alpha<1, \phi^{\mathrm{i}}$ is strictly concave in $\mathrm{k}^{\mathrm{i}}$, since, from $(6), \partial^{2} \phi^{\mathrm{i}} /\left(\partial \mathrm{k}^{\mathrm{i}}\right)^{2}=\mathrm{y}^{\mathrm{J}}(1-\alpha) \mathrm{w}^{\mathrm{o}} \sigma(\mathrm{i}) \theta \mathrm{h}^{\prime \prime}\left(\mathrm{k}^{\mathrm{i}}\right)<0$.

${ }^{30}$ If $\phi^{0}>0$, then since (7) implies $\phi^{\mathrm{i}}>0$ for all $\mathrm{i} \in[0, \mathrm{~N}], \mathrm{T}$ is not defined.
} 
place in the keiretsu only if this raises efficiency relative to importing. Thus, for $\mathrm{i} \geq \mathrm{T}$, the rent from investment $\mathrm{k}^{\mathrm{i}}$, shown as the difference between $\mathrm{c}(\mathrm{i})$ and the dashed line, $\mathrm{c}(\mathrm{i})$ - $\mathrm{r}(\mathrm{i})$, more than offsets the efficiency gap so as to at least cover the investment cost. For $\mathrm{i}<\mathrm{T}$, the difference between these lines is the rent that would have been created if the part had been produced in the keiretsu.

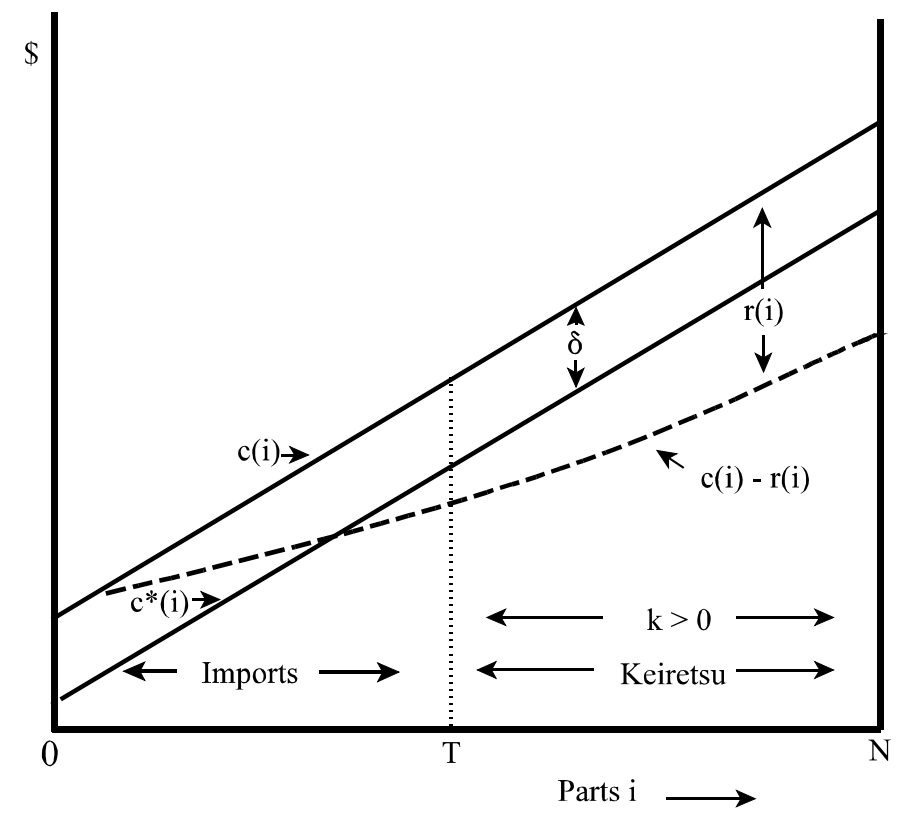

Fig. 1: Costs and the range of imported parts

From (8), using (7), since $y^{\mathrm{J}}$ varies exogenously due to a VER, it is useful to express the marginal part $\mathrm{T}$ as a function $\mathrm{T}=\mathrm{T}\left(\mathrm{y}^{\mathrm{J}} ; \theta\right)$, where $\mathrm{dT} / \mathrm{dy}^{\mathrm{J}}<0$ from (A4) of the Appendix. The increase in profit associated with an increase in $\mathrm{y}^{\mathrm{J}}$ allows more $\mathrm{J}$-suppliers to remain in business and hence reduces the range of imported parts. Also, since T varies due to a VIE (see next section), we express the J-maker's marginal cost as $\gamma=\gamma\left(\mathrm{T}, \mathrm{y}^{\mathrm{J}} ; \theta\right)$, where $\gamma=\int_{0}{ }^{\mathrm{T}} \mathrm{c}^{* \mathrm{i}} \mathrm{di}+\int_{\mathrm{T}}{ }^{\mathrm{N}} \gamma^{\mathrm{i}} \mathrm{di}+\mathrm{w}^{\mathrm{o}}$. Letting $\mathrm{C}^{*}(\mathrm{~N}) \equiv \int_{0}{ }^{\mathrm{N}} \mathrm{c}^{*}(\mathrm{i})$ di denote the total cost of parts if all parts are imported and using $\gamma^{\mathrm{i}}=\mathrm{c}^{* \mathrm{i}}-\alpha\left(\mathrm{r}^{\mathrm{i}}-\delta\right)$ from $(4), \gamma$ can be rearranged into the form:

$$
\gamma=\gamma\left(\mathrm{T}, \mathrm{y}^{\mathrm{J}} ; \theta\right)=\mathrm{C}^{*}(\mathrm{~N})-\int_{\mathrm{T}}{ }^{\mathrm{N}} \alpha\left(\mathrm{r}^{\mathrm{i}}-\delta\right) \mathrm{di}+\mathrm{w}^{\mathrm{o}} \text {. }
$$

As (9) shows, if $\alpha>0$, then the rents from relationship-specific investment reduce marginal cost below the level, $C^{*}(\mathrm{~N})+\mathrm{w}^{0}$, achieved when all parts are imported, but if $\alpha=0$, then $\gamma$ is constant whether or not parts are imported. Since this latter possibility would prevent a determinate outcome as to the set of imported parts under a VIE (see Proposition 2 below), we assume $\alpha>0$ and hence that $\alpha \in(0,1)$, giving all 
parties some bargaining power. It is true that if J-suppliers had all the bargaining power (i.e. if $\alpha=0$ ), they would set $\mathrm{k}^{\mathrm{i}}$ at an efficient level for a fixed level of $\mathrm{y}^{\mathrm{J}}$, but this is not optimal since, as shown by Spencer and Qiu (2001), a small increase in $\alpha$ would reduce the J-maker's marginal cost, leading to an increase in output and aggregate $\mathrm{J}$-supplier (and keiretsu) profit ${ }^{31}$.

Now considering the determination of output, since at the Nash equilibrium in $\mathrm{y}^{\mathrm{J}}, \mathrm{y}^{\mathrm{A}}$ and $\mathrm{k}^{\mathrm{i}}$, the $\mathrm{J}$ maker sets $\mathrm{y}^{\mathrm{J}}$ treating $\mathrm{k}^{\mathrm{i}}$ (and $\mathrm{y}^{\mathrm{A}}$ ) as fixed, it follows (see (9)) that the J-maker takes $\mathrm{r}^{\mathrm{i}}$ and hence $\gamma$ as fixed. Thus, there is no strategic role for output in influencing the prices paid for parts at the second stage bargaining game. Since the A-maker sets $\mathrm{y}^{\mathrm{A}}$ to maximize $\pi^{\mathrm{A}}$ as in (3) taking $\mathrm{y}^{\mathrm{J}}$ (and $\mathrm{k}^{\mathrm{i}}$ ) as given, final-good outputs, $\mathrm{y}^{\mathrm{J}}$ and $\mathrm{y}^{\mathrm{A}}$ satisfy the standard Cournot first order conditions:

$$
\begin{aligned}
& \pi_{\mathrm{J}}^{\mathrm{J}} \equiv \partial \pi^{\mathrm{J}} / \partial \mathrm{y}^{\mathrm{J}}=\mathrm{P}+\mathrm{y}^{\mathrm{J}} \mathrm{P}^{\prime}-\gamma=0, \\
& \pi^{\mathrm{A}}{ }_{\mathrm{A}} \equiv \partial \pi^{\mathrm{A}} / \partial \mathrm{y}^{\mathrm{A}}=\mathrm{P}+\mathrm{y}^{\mathrm{A}} \mathrm{P}^{\prime}-\gamma^{*}=0,
\end{aligned}
$$

where subscripts $\mathrm{J}$ and A represent partial derivatives with respect to $\mathrm{y}^{\mathrm{J}}$ and $\mathrm{y}^{\mathrm{A}}$ respectively. Assuming that the following second order and stability conditions:

$$
\begin{aligned}
& \pi_{\mathrm{JJ}}^{\mathrm{J}}=2 \mathrm{P}^{\prime}+\mathrm{y}^{\mathrm{J}} \mathrm{p}^{\prime \prime}<0, \pi_{\mathrm{AA}}^{\mathrm{A}}=2 \mathrm{P}^{\prime}+\mathrm{y}^{\mathrm{A}} \mathrm{P}^{\prime \prime}<0 \text { and } \\
& \mathrm{H}^{\mathrm{o}} \equiv \pi_{\mathrm{JJ}}^{\mathrm{J}} \pi_{\mathrm{AA}}^{\mathrm{A}}-\pi_{\mathrm{JA}}^{\mathrm{J}} \pi^{\mathrm{A}}{ }_{\mathrm{AJ}}=\mathrm{p}^{\prime}\left(3 \mathrm{p}^{\prime}+\mathrm{Yp}^{\prime \prime}\right)>0,
\end{aligned}
$$

hold globally, conditions (10) define equilibrium output levels, $\mathrm{y}^{\mathrm{J}}=\mathrm{y}^{\mathrm{J}}(\gamma)$ and $\mathrm{y}^{\mathrm{A}}=\mathrm{y}^{\mathrm{A}}(\gamma)$ where the constant $\gamma^{*}$ is omitted for convenience. However, the dependence of $\mathrm{k}^{\mathrm{i}}=\mathrm{k}\left(\sigma^{\mathrm{i}}, \mathrm{y}^{\mathrm{J}}\right)$ on $\mathrm{y}^{\mathrm{J}}$ means that $\gamma=\gamma\left(\mathrm{T}, \mathrm{y}^{\mathrm{J}}\right)$ is also dependent on $\mathrm{y}^{\mathrm{J}}$ and hence we require the additional (global) stability conditions:

$$
\pi_{J J}^{\mathrm{J}}-\mathrm{d} \gamma / \mathrm{dy}{ }^{\mathrm{J}}<0 ; \mathrm{H} \equiv \mathrm{H}^{\mathrm{o}}-\pi_{\mathrm{AA}}^{\mathrm{A}}\left(\mathrm{d} \gamma / \mathrm{dy} \mathrm{J}^{\mathrm{J}}\right)>0
$$

where for $\alpha>0, d \gamma / d y^{J}=(\partial \gamma / \partial \mathrm{T})\left(\mathrm{dT} / \mathrm{dy}^{\mathrm{J}}\right)+\partial \gamma / \partial \mathrm{y}^{\mathrm{J}}<0$ from (A4) and (A5) of the Appendix. From (10), treating $\gamma$ as a constant with respect to $\mathrm{y}^{\mathrm{J}}$, we first obtain the standard result that an increase in $\gamma$ reduces $\mathrm{y}^{\mathrm{J}}$ and then, using (12) to take account of the effect of $y^{\mathrm{J}}$ on $\gamma$, we obtain:

$$
\mathrm{dy}^{\mathrm{J}} / \mathrm{d} \gamma=\pi_{\mathrm{AA}}^{\mathrm{A}} / \mathrm{H}^{\mathrm{o}}<0 ; 1-(\mathrm{dy} / \mathrm{d} \gamma)\left(\mathrm{d} \gamma / \mathrm{dy} \mathrm{J}^{\mathrm{J}}\right)=\mathrm{H} / \mathrm{H}^{\mathrm{o}}>0
$$

In the event that $\mathrm{T}$ is fixed due to a VIE, we require $1-(\mathrm{dy} / \mathrm{d} \gamma)\left(\partial \gamma / \partial \mathrm{y}^{\mathrm{J}}\right)>0$, but since $\mathrm{d} \gamma / \mathrm{dy} \mathrm{y}^{\mathrm{J}}<\partial \gamma / \partial \mathrm{y}^{\mathrm{J}}<0$,

\footnotetext{
${ }^{31} \mathrm{~J}$-suppliers benefit due to $\mathrm{p}^{\mathrm{i}}-\mathrm{c}^{\mathrm{i}}>0$, but the J-maker would prefer a higher value of $\alpha$.
} 
this condition is implied by (13). Also, for consideration of trade policy, it is useful to assume that outputs are strategic substitutes (i.e. $\pi_{\mathrm{ij}}^{\mathrm{i}}=\mathrm{p}^{\prime}+\mathrm{y}^{\mathrm{i}} \mathrm{p}^{\prime \prime}<0$ for $\mathrm{i} \neq \mathrm{j}$ ) and hence that

$$
\mathrm{dy}^{\mathrm{A}} / \mathrm{dy}^{\mathrm{J}}=-\pi_{\mathrm{AJ}}^{\mathrm{A}} / \pi_{\mathrm{AA}}^{\mathrm{A}}<0 ; \mathrm{dy}^{\mathrm{J}} / \mathrm{dy}^{\mathrm{A}}=-\pi_{\mathrm{JA}}^{\mathrm{J}} / \pi_{\mathrm{JJ}}^{\mathrm{J}}<0 .
$$

Finally, taking into account the endogenous determination of output and investment and letting a superscript $\mathrm{F}$ denote values at free trade, the set of imported parts is given by $\Delta^{\mathrm{F}} \equiv\left\{\mathrm{i}: \mathrm{i}<\mathrm{T}^{\mathrm{F}}\right\}$, where

$$
\mathrm{T}^{\mathrm{F}}=\mathrm{T}\left(\mathrm{y}^{\mathrm{JF}} ; \theta\right) \text { for } \mathrm{y}^{\mathrm{JF}}=\mathrm{y}^{\mathrm{J}}\left(\gamma^{\mathrm{F}}\right) \text { and } \gamma^{\mathrm{F}}=\gamma\left(\mathrm{T}^{\mathrm{F}}, \mathrm{y}^{\mathrm{J}}\left(\gamma^{\mathrm{F}}\right) ; \theta\right) \text {. }
$$

Letting $\theta^{\mathrm{T}=\mathrm{N}}$ represent the value of $\theta$ at which supplier $\mathrm{N}$ just breaks even (i.e. $\phi\left(\mathrm{N}, \mathrm{y}^{\mathrm{J}} ; \theta^{\mathrm{T}=\mathrm{N}}\right)=0$ ), then $\mathrm{T}^{\mathrm{F}}=$ $\mathrm{N}$ and all other parts are imported. Similarly, letting $\theta^{\mathrm{T}=0}$ satisfy $\phi\left(0, \mathrm{y}^{\mathrm{J}} ; \theta^{\mathrm{T}=0}\right)=0$, then $\mathrm{T}^{\mathrm{F}}=0$ and all parts are produced in the keiretsu. Since, as shown in (A8) of the Appendix, an increase in $\theta$ causes a reduction in $\mathrm{T}^{\mathrm{F}}$, parts are fully supplied by imports for $\theta \in\left[0, \theta^{\mathrm{T}=\mathrm{N}}\right)$ and by the keiretsu for ${ }^{32} \theta \in\left[\theta^{\mathrm{T}=0}, \theta^{\mathrm{max}}\right]$. To ensure some possibility of production by $\mathrm{J}$-suppliers, we assume $\theta \geq \theta^{\mathrm{T}=\mathrm{N}}$.

\section{Voluntary import expansion: VIE}

This section concerns the effects of VIEs designed to open the Japanese market for imported parts. Three types of VIE's are considered: a content VIE, a market-share VIE and a total-value VIE. A content VIE specifies a minimum level of U.S. content per auto produced in Japan, whereas the market-share target under a market-share VIE depends on U.S. content per auto, but also on the way Japanese parts are valued. A natural possibility, which we focus on here, is that Japanese parts are valued at their marginal cost, $c^{\mathrm{i}}$, of production $^{33}$. This reflects the idea that the rents enjoyed by the J-maker from the purchase of keiretsu produced parts and also the prices of these parts as obtained through bargaining would be hard for outsiders to observe, particularly if the observers are foreign, such as the U.S. government. Marginal cost, $\mathrm{c}^{\mathrm{i}}$, is more easily observable, since $c^{i}$ is the price that supplier $i$ would quote if it were to sell to outside firms, such as

\footnotetext{
${ }^{32}$ We assume that $\theta^{\max }$ is sufficiently large that $\phi\left(0, \mathrm{y}^{\mathrm{J}} ; \theta^{\max }\right)>0$ and hence that $\theta^{\mathrm{T}=0}<\theta^{\max }$.

${ }^{33}$ As shown in an earlier working paper, Qiu and Spencer (2000), our results also apply if Japanese parts are valued at the J-maker's net marginal cost, $\gamma^{\mathrm{i}}=\mathrm{p}^{\mathrm{i}}-\mathrm{r}^{\mathrm{i}}$. The valuation method for parts is important for Proposition 2 (below), showing that the VIE is satisfied by importing parts in the order of lowest to highest cost-share, but given this result, the particular method used does not affect the further insights.
} 
the U.S. automaker. The third possibility, a total-value VIE, also depends on U.S. content per auto, but in addition, induced changes in Japanese production of autos play a central role in achievement of the target.

As argued by Krishna et al. (1998), the effects of a VIE can depend crucially on how it is implemented. In the current setting, it seems most natural to suppose that the J-maker is responsible for achieving compliance with the policy. One possibility, developed in the next section, is that the J-maker's actions are motivated by a threat of a VER or tariff. However, our results also apply if compliance by the automaker to the VIE is achieved by direct pressure from the Japanese government as was partly the case in the 1986 semiconductor agreement (see Irwin, 1996, pp 11-12). Pressure to make buying firms responsible is understandable, particularly since the complaints leading to VIEs commonly involve beliefs of unfair procedures by buying firms. For example, with respect to auto parts, U.S. firms complained that they had difficulty in obtaining the necessary information for bids (see Levinsohn, 1997, pp.15-16).

With respect to the order of moves, we assume that governments commit to trade policy, such as a VIE, a VER or a tariff, prior to any actions by firms. In response to a VIE, the J-maker makes a commitment at stage 0 to import at least the set of parts denoted by $\Delta$. The quantity of these imports is subsequently determined by the J-maker's need for parts arising from its equilibrium level of output. Since the J-maker sees through to the outcome of the game, the set $\Delta$ is chosen to ensure compliance with the VIE (if feasible). There are no other changes in the order of moves. Decisions as to investments, $\mathrm{k}^{\mathrm{i}}$, and final-good outputs, $\mathrm{y}^{\mathrm{J}}$ and $\mathrm{y}^{\mathrm{A}}$, are made at stage 1, with bargaining over the prices for parts within the keiretsu at stage 2.

It is important to emphasis that at stage 0 , the $\mathrm{J}$-maker makes no commitment as to the set of parts to be purchased from J-suppliers. These parts are endogenously determined as before, leaving open the possibility that further parts in addition to $\Delta$ will be imported. Thus, while compliance with the VIE requires some commitment by the J-maker as to a minimum set of imports, the model maintains the feature that the J-suppliers do not get an advance contract before making relationship-specific investments ${ }^{34}$. It is also important that the modification of the model to allow for a first mover capability of the J-maker at stage 0

\footnotetext{
${ }^{34} \mathrm{~A}$ commitment by the J-maker at stage 0 not to import a particular part would change the threat point at the bargaining equilibrium, affecting the incentives for investment and the prices paid for parts.
} 
confers no strategic advantage and has no effect on the outcome of the model under free trade. To show this, recalling that $\Delta^{\mathrm{F}}=\left\{\mathrm{i}: \mathrm{i}<\mathrm{T}^{\mathrm{F}}\right\}$ represents the set of parts that would be imported at free trade, since J-suppliers for $\mathrm{i} \in \Delta^{\mathrm{F}}$ would anyway make losses from production, an up-front commitment to import parts in $\Delta^{\mathrm{F}}$ does not change the outcome. Secondly, as we show in Proposition 1, the import of any additional part $\mathrm{j} \notin \Delta^{\mathrm{F}}$ serves to raise the J-maker's marginal cost due to a loss of relationship-specific investment. Thus the Jmaker's output and profit falls (and the A-maker's profit rises). Consequently the J-maker would not use its commitment ability to import additional parts under free trade and any difference in outcome under the VIE is due to the effects of the VIE and not to a change in the strategic behavior of firms.

To further explain Proposition 1, suppose that at stage 0, the J-maker announces the import of part $\mathrm{j} \notin \Delta^{\mathrm{F}}$. Since $\mathrm{r}^{\mathrm{j}}-\delta>0$, the J-maker's marginal cost, $\gamma^{\mathrm{j}} \equiv \mathrm{c}^{* \mathrm{j}}-\alpha\left(\mathrm{r}^{\mathrm{j}}-\delta\right)$, for part $\mathrm{j} \in\left[\mathrm{T}^{\mathrm{F}}, \mathrm{N}\right]$ from supplier $\mathrm{j}$ is strictly less than the import price, $\mathrm{c}^{* \mathrm{j}}$, giving rise to a direct increase in the J-maker's marginal cost of:

$$
\mathrm{m}^{\mathrm{j}} \equiv \mathrm{c}^{* \mathrm{j}}-\gamma^{\mathrm{j}}=\alpha\left(\mathrm{r}^{\mathrm{j}}-\delta\right)>0 \text { for } \alpha>0 \text { and } \mathrm{j} \in\left[\mathrm{T}^{\mathrm{F}}, \mathrm{N}\right] \text {. }
$$

At stage 1 , the increase in the direct cost due to $\mathrm{k}^{\mathrm{j}}=0$ will cause a reduction in $\mathrm{y}^{\mathrm{J}}$ and a reduction in $\mathrm{k}^{\mathrm{i}}$ and $r^{i}$ for $i \neq j$ and $i \in\left[T^{F}, N\right]$, reinforcing the fall in the J-maker's profit. The A-maker's profit increases since outputs are strategic substitutes. The proofs of all propositions, including Proposition 1, are in the Appendix. Proposition 1. For $\alpha \in(0,1)$, commitment by the J-maker to an import set $\Delta$ that includes at least one part $j \notin \Delta^{F}$ will result in (i) an increase in marginal cost for part j, (ii) higher $\gamma$ and lower $k^{i}, r^{i}, y^{J}$ and $\pi^{J}$ and (iii) higher $\pi^{A}$ compared with free trade.

Proposition 1 reflects the fact that the use of keiretsu suppliers raises efficiency. However, this conclusion is quite different from common beliefs arising without consideration of the keiretsu structure. Part of the impetus for the U.S./Japan Auto Agreement arose from complaints that keiretsu "unfairly" purchase more expensive Japanese auto parts rather than cheaper U.S. imports. Thus, a VIE directed at opening the Japanese parts market was expected to reduce Japanese production costs (lower $\gamma$ ) and raise Japanese output of autos ( larger $\mathrm{y}^{\mathrm{J}}$ ). As a result, in addition to an increase in U.S. market share, a VIE was expected to increase the total Japanese demand for parts, further raising the value of U.S. parts exports. Since, taking into account the endogenous determination of relationship-specific investment within keiretsu, a VIE would 
reduce Japanese production of autos, our results suggest that a VIE requiring a given market share for parts could be significantly less effective than expected in raising the value of U.S. parts exports.

Now turning to the question as to the types of parts that will be imported first in response to the VIE, in making this choice (at stage 0 ) the J-maker is assumed to maximize profit subject to satisfying the VIE. Suppose that the $\mathrm{J}$-maker announces the import of just one part $\mathrm{j} \notin \Delta^{\mathrm{F}}$ at stage 0 . To the extent that part $\mathrm{j}$ has a higher cost-share, there is a greater loss of rent from investment, which causes the direct cost, $\mathrm{m}^{\mathrm{j}}$, incurred by the J-maker to rise ${ }^{35}$. This suggests, as shown in Proposition 2, that to satisfy a VIE, additional parts $\mathrm{j} \in$ $\left[\mathrm{T}^{\mathrm{F}}, \mathrm{N}\right]$ will be imported in the order from lowest to highest cost-share. However, to prove this result ${ }^{36}$, it is necessary to also take into account the contribution, $\mathrm{c}^{* \mathrm{j}}$, of each additional imported part towards achieving an increase in U.S. content. Consequently, it is the effect of a higher cost-share on $\mathrm{m}^{\mathrm{j} / \mathrm{c}^{* \mathrm{j}}}$ that is important, and since the use of higher cost parts will allow the VIE target to be met with a smaller range of imported parts ( $\mathrm{c}^{* \mathrm{j}}$ is also increasing in $\mathrm{j}$ ), this complicates the proof and the result is not obvious.

Proposition 2. Assume $\alpha \in(0,1)$. To satisfy (i) a content VIE, (ii) a market-share VIE or (iii) for linear demand, a total-value VIE, additional parts, $j \in\left[T^{F}, N\right]$, above the free trade level will be imported in the order determined by increasing cost-shares (i.e. import lower $\sigma^{j}$ ).

As a result of Proposition 2, a (feasible) VIE target for any of the three forms of VIE is implemented by the import of the set of parts denoted $\Delta^{\bar{T}} \equiv\{\mathrm{i}: \mathrm{i}<\overline{\mathrm{T}}\}$ where $\overline{\mathrm{T}} \in\left(\mathrm{T}^{\mathrm{F}}, \mathrm{N}\right]$ is the smallest value of $\mathrm{T}$ at which the particular target is satisfied. To see this, letting $\mathrm{v}^{*}(\mathrm{~T}) \equiv \int_{0}^{\mathrm{T}} \mathrm{c}^{* i}$ di represent U.S. content per auto from all parts $\mathrm{i}<\mathrm{T}$, then, since $\mathrm{v}^{* \prime}(\mathrm{T})=\mathrm{c}^{* \mathrm{~T}}>0$, for any target content, $\overline{\mathrm{v}}^{*}$, there is a unique value of $\mathrm{T}=\overline{\mathrm{T}}$ satisfying $\mathrm{v}^{*}(\overline{\mathrm{T}})=\overline{\mathrm{v}}^{*}$ and, as $\overline{\mathrm{v}}^{*}$ increases, the required import set, $\Delta^{\bar{T}}$, expands though an increase in $\overline{\mathrm{T}}$. Similarly, letting $v(T) \equiv \int_{T}^{N} c^{i}$ di represent Japanese content, then the U.S. market share is given by $S^{*}(T)=v^{*}(T) /\left(v^{*}(T)\right.$

\footnotetext{
${ }^{35}$ From (16) and (A2) of the Appendix, we obtain $\mathrm{dm} / \mathrm{dj}=\alpha\left(\mathrm{dr}^{\mathrm{j}} / \mathrm{d}^{\mathrm{j}}\right) \sigma^{\prime}(\mathrm{j})>0$ for $\alpha>0$.

${ }^{36}$ Linear demand simplifies the proof of Proposition 2(iii) for the total-value VIE by making $\mathrm{dy} / \mathrm{d} \gamma$ constant. The result generalizes to other demand structures if $\mathrm{d}^{2} \mathrm{y}^{\mathrm{J}} /(\mathrm{d} \gamma)^{2}<0$ so the effect of an increase in $\gamma$ in reducing output is magnified as $\gamma$ increases or, alternatively, if $\mathrm{d}^{2} \mathrm{y}^{\mathrm{J}} /(\mathrm{d} \gamma)^{2}>0$ but sufficiently small.
} 
$+\mathrm{v}(\mathrm{T}))$ and any required market share, $\overline{\mathrm{S}}^{*}$, is achieved at the unique value $\mathrm{e}^{37}$ of $\mathrm{T}=\overline{\mathrm{T}}$ satisfying $\mathrm{S}^{*}(\overline{\mathrm{T}})=\overline{\mathrm{S}}^{*}$. In addition, letting $\gamma^{\mathrm{T}}$ and $\mathrm{V}^{*^{\mathrm{T}}}$ respectively represent the J-maker's marginal cost and the total value of U.S. exports of parts at $\mathrm{T}=\overline{\mathrm{T}}$, then $\mathrm{V}^{* \mathrm{~T}} \equiv \mathrm{v}^{*}(\overline{\mathrm{T}}) \mathrm{y}^{\mathrm{J}}\left(\gamma^{\mathrm{T}}\right)$ where $\gamma^{\mathrm{T}} \equiv \gamma\left(\overline{\mathrm{T}}, \mathrm{y}^{\mathrm{J}}\left(\gamma^{\mathrm{T}}\right) ; \theta\right)$. Since the import of additional parts raises U.S. content per auto, but reduces the J-maker's output, it is possible that a greater range of imported parts can actually lower the total value of imports ${ }^{38}\left(\right.$ making $\left.\mathrm{dV}^{* \mathrm{~T}} / \mathrm{dT}<0\right)$ and hence that there may be more than one value of $\mathrm{T}$ at which some total-value target, $\overline{\mathrm{V}}^{*}$, is satisfied. However, the J-maker will set $\overline{\mathrm{T}}$ equal to the smallest value of $T \in\left(T^{\mathrm{F}}, \theta\right)$ satisfying $V^{* T}=\overline{\mathrm{V}}^{*}$ so as to minimize the increase in marginal cost due to the loss of relationship-specific investment.

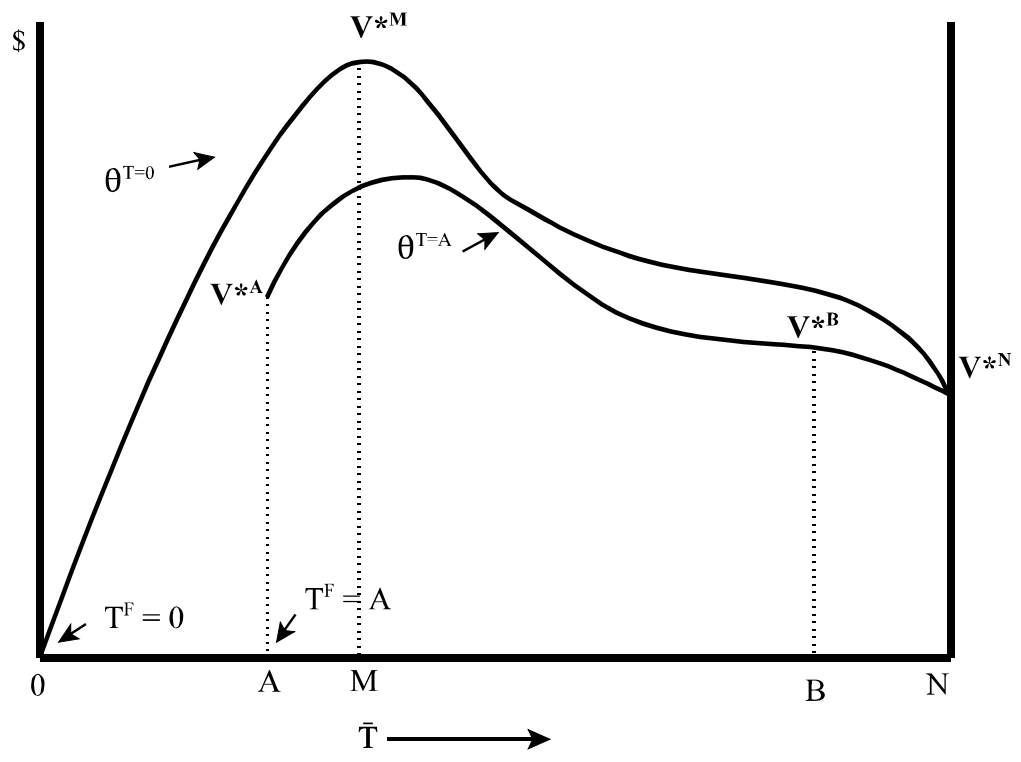

Fig. 2: Value of U.S. parts exports

As illustrated in Fig. 2, we can gain some insights as to the pattern of response in the total value of U.S. parts exports based on the size or restrictiveness of the VIE target as well as on the magnitude of the productivity, $\theta$, of relationship-specific investment. If $\theta$ is sufficiently large that there are no imports at free trade (i.e. if $\theta=\theta^{\mathrm{T}=0}$ and hence $\mathrm{T}^{\mathrm{F}}=0$ ), then any VIE, even a drastic VIE which forces Japan to use only

\footnotetext{
${ }^{37}$ Since an increase in T (and U.S. content) reduces Japanese content $\left(i . e . v^{\prime}(T)=-c^{T}<0\right.$ ), we obtain $S^{* \prime}(T)$ $>0$, which implies that $\mathrm{T}$ satisfying $\mathrm{S}(\overline{\mathrm{T}})=\overline{\mathrm{S}}^{*}$ is unique and that $\mathrm{d} \overline{\mathrm{T}} / \mathrm{d} \overline{\mathrm{S}}^{*}>0$.
}

${ }^{38}$ We have $\mathrm{dV}^{* \mathrm{~T}} / \mathrm{dT}=\mathrm{y}^{\mathrm{J}} \mathrm{c}^{*}(\mathrm{~T})+\mathrm{v}^{*}(\mathrm{~T})\left(\mathrm{dy}^{\mathrm{J}} / \mathrm{dT}\right)$ and $\mathrm{dy}^{\mathrm{J}} / \mathrm{dT}<0$ from (A9) in the Appendix. 
imported parts, must result in an increase in the value of U.S. exports. Thus, as shown by the solid line from the origin at $\mathrm{T}^{\mathrm{F}}=0$, corresponding to $\theta=\theta^{\mathrm{T}=0}, \mathrm{~V}^{* \mathrm{~T}}$ is positive for any $\overline{\mathrm{T}}>0$, reaching a value of $\mathrm{V}^{* \mathrm{~N}}$ under a drastic, content or market share VIE, which is satisfied only at $\overline{\mathrm{T}}=\mathrm{N}$. However, it is quite possible that the value of U.S. exports is not maximized at $\overline{\mathrm{T}}=\mathrm{N}$. As Fig. 2 indicates, $\mathrm{V}^{* \mathrm{~T}}$ initially increases with $\overline{\mathrm{T}}$, but, as the VIE becomes more restrictive, the reduction in the J-maker's output may eventually cause $\mathrm{V}^{* \mathrm{~T}}$ to fall, leading to an internal maximum ${ }^{39}$, shown at $\overline{\mathrm{T}}=\mathrm{M}$, in which the keiretsu continues to produce parts $\mathrm{i} \geq \mathrm{M}$. Obviously, in this case, a drastic VIE, or indeed any content or market-share VIE that requires $\overline{\mathrm{T}}>\mathrm{M}$, would not maximize the value of U.S. exports.

As this possibility suggests, a content or market-share VIE, particularly if it is highly restrictive, may actually be counterproductive as a means of raising the total value of U.S. parts exports. By contrast, a totalvalue VIE has the advantage of retaining more flexibility for the J-maker as to the range of parts to be imported. Consequently, faced with a total-value VIE requiring the same total value of U.S. exports as would be achieved from a content or market-share VIE at some $\overline{\mathrm{T}}>\mathrm{M}$, the J-maker would import fewer parts (with $\overline{\mathrm{T}}$ $<$ M) so as to satisfy the VIE based on a lower U.S. content per auto, but a higher level of production. However, a less restrictive content or market-share VIE that can be satisfied for some $\overline{\mathrm{T}} \leq \mathrm{M}$ would have exactly the same effects as a total-value VIE with the same total value of U.S. exports.

Since the J- maker's loss of output tends to be larger the greater the productivity, $\theta$, an internal maximum for U.S. exports is most likely if $\theta=\theta^{\mathrm{T}=0}$ (see Fig. 2) and there are no (or very few) exports at free trade. However, an internal maximum is also possible for lower productivity settings in which a significant range of U.S. parts are exported at free trade. As illustrated by the line from $\mathrm{V}^{* \mathrm{~A}}$ to $\mathrm{V}^{* \mathrm{~N}}$, corresponding to $\theta^{\mathrm{T}=\mathrm{A}}$ and $\mathrm{T}^{\mathrm{F}}=\mathrm{A}$, a lower productivity $\theta$ results in a positive value of exports, $\mathrm{V}^{* \mathrm{~A}}$, at free trade, but, the value of exports for any given $\overline{\mathrm{T}}$ (below $\mathrm{N}$ ) is reduced ${ }^{40}$. For $\theta=\theta^{\mathrm{T}=\mathrm{A}}$, a small VIE (of any type) at free trade would

\footnotetext{
${ }^{39} \mathrm{~A}$ sufficient condition for an internal maximum is $\mathrm{dV}^{* \mathrm{~T}} / \mathrm{d} \overline{\mathrm{T}}<0$ at $\overline{\mathrm{T}}=\mathrm{N}$. Since an increase in U.S. content per auto magnifies the reduction in the value of U.S. exports from any given fall in $\mathrm{y}^{\mathrm{J}}$, it becomes more likely that $\mathrm{dV}^{* \mathrm{~T}} / \mathrm{d} \overline{\mathrm{T}}<0$ as $\overline{\mathrm{T}}$ is increased.

${ }^{40}$ Since $\left.\left(\mathrm{dV}^{* \mathrm{~T}} / \mathrm{d} \theta\right)\right|_{\mathrm{T}}=\mathrm{V}^{*}(\overline{\mathrm{T}})\left(\left.(\mathrm{dy} / \mathrm{d} \theta)\right|_{\mathrm{T}}\right)>0$ (see (A9)), $\mathrm{V}^{* \mathrm{~T}}$ is increasing in $\theta$ for any given $\overline{\mathrm{T}}<\mathrm{N}$. For a drastic VIE at $\overline{\mathrm{T}}=\mathrm{N}$, there is no effect of $\theta$, since there is no $\mathrm{J}$-supplier production or investment.
} 
increase the value of U.S. exports, but imposition of a more restrictive VIE, such as a content or market-share VIE at $\overline{\mathrm{T}}=\mathrm{B}$ or a drastic VIE at $\overline{\mathrm{T}}=\mathrm{N}$ would reduce the value of these exports below the level, $\mathrm{V}^{* \mathrm{~A}}$, achieved at free trade. Moreover, at an even lower productivity (and higher free trade level of imports), it is possible that the value of U.S. exports is maximized at free trade and hence would be reduced by any market-share VIE, small or large. As this last possibility indicates, a total-value VIE with any target above the free-trade level may actually not be feasible.

\section{Voluntary export restraint (VER) or tariff}

This section develops the effects of a VER, or alternatively a tariff, applied to U.S. imports of Japanese autos as they work through the vertically connected markets, taking into account the further linkages to relationship-specific investment within the keiretsu. This is of interest in itself since VERs and tariffs have commonly been applied to Japanese auto exports, but the main objective is to provide comparisons with the effects of VIEs so as to gain a better understanding of the implications of both types of policies for access to the Japanese market for imported parts.

A VER specifies a maximum value of imports of a particular good from a particular country. Since we have assumed that all of the final good is consumed in the U.S., a binding VER would limit keiretsu production and exports of autos to a given level, denoted by $\bar{y}^{\mathrm{J}}$ where $\bar{y}^{\mathrm{J}}<\mathrm{y}^{\mathrm{J}}(\gamma)$. Since there is no change in the free trade relationships involving parts suppliers, similar to (15), the VER gives rise to a set of imported parts, $\Delta^{\mathrm{y}} \equiv\left\{\mathrm{i}: \mathrm{i}<\mathrm{T}^{\mathrm{F}}\right.$ for $\left.\mathrm{T}^{\mathrm{F}}=\mathrm{T}\left(\overline{\mathrm{y}}^{\mathrm{J}} ; \theta\right)\right\}$ and a marginal cost $\gamma^{\mathrm{y}} \equiv \gamma\left(\mathrm{T}\left(\overline{\mathrm{y}}^{\mathrm{J}} ; \theta\right), \overline{\mathrm{y}}^{\mathrm{J}} ; \theta\right)$ for the $\mathrm{J}$-maker where the superscript y represents equilibrium values under a VER. This analysis is easily adapted to apply to a tariff. Given Cournot behavior in the final-good market, a VER differs from a tariff only because the J-maker rather than the U.S. government receives the quota rents. Thus if a specific tariff, denoted t, restricts the J-maker's output to $\mathrm{y}^{\mathrm{Jt}}$, then the J-maker's marginal cost is given by $\tau \equiv \gamma\left(\mathrm{T}\left(\mathrm{y}^{\mathrm{Jt}} ; \theta\right), \mathrm{y}^{\mathrm{Jt}} ; \theta\right)+\mathrm{t}$ for $\mathrm{y}^{\mathrm{Jt}}=\mathrm{y}^{\mathrm{J}}(\tau)$. Setting $\mathrm{y}^{\mathrm{Jt}}$ $=\bar{y}^{\mathrm{J}}$, then, since $\tau=\gamma^{\mathrm{y}}+\mathrm{t}$, the J-maker's marginal cost is higher by the amount of the tariff, but the import set, $\Delta^{\mathrm{y}}$, is unchanged and the tariff is otherwise equivalent to the VER.

We first show, in Proposition 3, that a VER (or tariff) applied to final-good exports has a market 
opening effect with respect to the range and market share of imported parts. This is due to the endogenous response of relationship-specific investment. By reducing the J-maker's output, the VER (or tariff) causes this investment to fall and, since production by some J-suppliers becomes unprofitable, $T\left(\overline{\mathrm{y}}^{\mathrm{J}}\right)$ and hence the range of imported parts, $\Delta^{\mathrm{y}}$, is increased. This increases U.S. content per auto and hence U.S. suppliers gain a larger share of the Japanese parts market. Not surprisingly, keiretsu investment is crucially important for this result. In standard models without relationship-specific investments, a reduction in a country's final-good output would reduce that country's demand for intermediate-goods, including the demand for imports with no systematic effect on the share of imported parts. However, just as for a content or market-share VIE, it is not necessarily the case that a VER would raise the total value of U.S. exports of parts. If relationshipspecific investment is sufficiently productive that there are no or very few exports of parts at free trade (i.e. if $\theta$ is close to $\theta^{\mathrm{T}=0}$ ), then the effect of the VER in causing some parts to be exported would dominate the effect of the VER in reducing the demand for any given part and the value of U.S. parts exports would rise. By contrast, if the free-trade value of parts exports is large (due to low $\theta$ ), the effect of the VER in reducing the overall demand for parts could dominate.

Proposition 3. A VER (or tariff) reduces the J-maker's output, $\bar{y}^{J}$, and relationship-specific investment, $k^{i}$, but raises $T\left(\bar{y}^{J}\right)$, enlarging the set $\Delta^{y}$ of imported parts and the U.S. share of the Japanese parts market.

Although a VER (tariff) and a VIE (all three types) both enlarge the range of imported parts and reduce keiretsu output, comparing the magnitudes of these effects, we show in Proposition 4((i) and (ii)) that the VIE is more effective in raising the range of imported parts (for a given level of the J-maker's output) and the VER is more effective in reducing the J-maker's output (for a given range of imported parts). Consequently, for both comparisons, the VIE is more effective than the VER in raising the total value of U.S. parts exports. Letting $\mathrm{V}^{* \mathrm{y}} \equiv \mathrm{v}^{*}(\mathrm{~T}) \overline{\mathrm{y}}^{\mathrm{J}}$ for $\mathrm{T}=\mathrm{T}\left(\overline{\mathrm{y}}^{\mathrm{J}}, \theta\right)$ represent the total value of U.S. parts exports under the VER and comparing the policies for the same value of these exports (i.e. for $\mathrm{V}^{* \mathrm{y}}=\mathrm{V}^{* \mathrm{~T}}$ ), it follows, as set out in Proposition 4(iii), that the import set is larger and the J-maker's output is smaller under the VER than the VIE. For this last result, we assume that the policies raise the value of U.S. exports in the relevant range: i.e. that, 


$$
\mathrm{dV}^{* \mathrm{~T}} / \mathrm{dT}>0 \text { for } \mathrm{T} \in\left[\mathrm{T}^{\mathrm{F}}, \overline{\mathrm{T}}\right] \text { and } \mathrm{dV}^{* \mathrm{y}} / \mathrm{dy}^{\mathrm{J}}<0 \text { for } \mathrm{y}^{\mathrm{J}} \in\left[\mathrm{y}^{\mathrm{J}}\left(\gamma^{\mathrm{F}}\right), \overline{\mathrm{y}}^{\mathrm{J}}\right] .
$$

Proposition 4. (i) For $y^{J}\left(\gamma^{T}\right)=\bar{y}^{J}$, the VIE enlarges the import set by more than the VER or tariff (i.e. $\bar{T}>$ $T\left(\bar{y}^{J}\right)$ ). (ii) For $\bar{T}=T\left(\bar{y}^{J}\right)$, the VER (tariff) restricts the J-maker's output by more than the VIE (i.e. $\bar{y}^{J}<$ $y^{J}\left(\gamma^{T}\right)$ ). (iii) Assume (17). If $V^{* y}=V^{* T}$, then the import set is larger and the J-maker's output is smaller under the VER (tariff) than the VIE (i.e. $T\left(\bar{y}^{J}\right)>\bar{T}$ and $\left.\bar{y}^{J}<y^{J}\left(\gamma^{T}\right)\right)$.

The basic insight is that a direct reduction in the range of keiretsu produced parts has less of an effect in reducing relationship-specific investment and hence less of an effect in reducing output than the same reduction in keiretsu produced parts achieved by a direct cut in output. Consequently, for the same total value of U.S. parts exports, the VER has more of an effect in reducing output and less of an effect in raising the range of imported parts than would a VIE. These results are not surprising based on the idea that the more direct policy should have more of an effect on the variable of interest (other things equal). Nevertheless, since the results depend on the relative strength of effects on investment decisions by many firms in response to policies applied at different stages of the vertical market, they are also not immediately obvious.

Both types of policies reduce the J-maker's profit due to the loss of output and relationship-specific investment. However, as Proposition 4(iii) suggests, for the same total value of U.S. exports, a VER would reduce the J-maker's profit by more than the VIE and, as set out in Proposition 5, it follows that a credible threat of such a VER is sufficient to induce the J-maker to comply with the VIE without the need for further pressure from the Japanese government ${ }^{41}$.

Proposition 5. Assume (17). If $V^{* y}=V^{* T}$, then the J-maker's profit is lower under the VER (tariff), making the credible threat of such a VER (tariff) sufficient to induce the J-maker to comply with the VIE.

In Fig. 3, starting from free trade (at point F), the path of $\mathrm{T}$ (import set) and output, $\mathrm{y}^{\mathrm{J}}$, as a VIE or a VER become more restrictive is shown by the solid lines FH and FG respectively. Each contour V*I $\mathrm{V}^{* I I}$

\footnotetext{
${ }^{41}$ There is empirical evidence that the U.S. 1981 VER on autos raised the profits of Japanese automakers (see Ries, 1993). If our model were relaxed to allow for more keiretsu automakers or for autos to be strategic complements, then Japanese automakers could also benefit from the VER. However, the effects of a tariff are robust and Propositions 3 and 4 are a consequence of the reduction in investment as output falls and do not depend on the assumption of strategic substitutes or whether J-maker profit rises or falls.
} 
or $\mathrm{V}^{* \mathrm{M}}$ represents the combination of the range of imported parts and the J-maker's output required to produce a constant total value of U.S. parts exports. The value of these exports ranges from $\mathrm{V}^{* \mathrm{I}}$ at free trade to the maximum value, $\mathrm{V}^{* \mathrm{M}}$, achievable under a VIE at $\overline{\mathrm{T}}=\mathrm{T}^{\mathrm{M}}$. The value, $\mathrm{V}^{* \text { II }}$, is reached with either a VIE at $\overline{\mathrm{T}}=\mathrm{T}^{\mathrm{A}}$ or with a VER at $\overline{\mathrm{y}}^{\mathrm{J}}=\mathrm{y}^{\mathrm{JB}}$. Since $\mathrm{y}^{\mathrm{JA}}>\mathrm{y}^{\mathrm{JB}}$ and $\mathrm{T}^{\mathrm{A}}<\mathrm{T}^{\mathrm{B}}$, this illustrates Proposition 4(iii). Since points $\mathrm{H}$ and $\mathrm{G}$ at $\mathrm{T}=\mathrm{N}$ are above $\mathrm{V}^{* \mathrm{I}}$ (and $\mathrm{V}^{* \mathrm{II}}$ ), Fig. 3 illustrates a case in which both a drastic VIE and VER would raise the value of exports above the free trade level. However, the value of U.S. parts exports is maximized at an internal VIE corresponding to $\overline{\mathrm{T}}=\mathrm{T}^{\mathrm{M}}$.

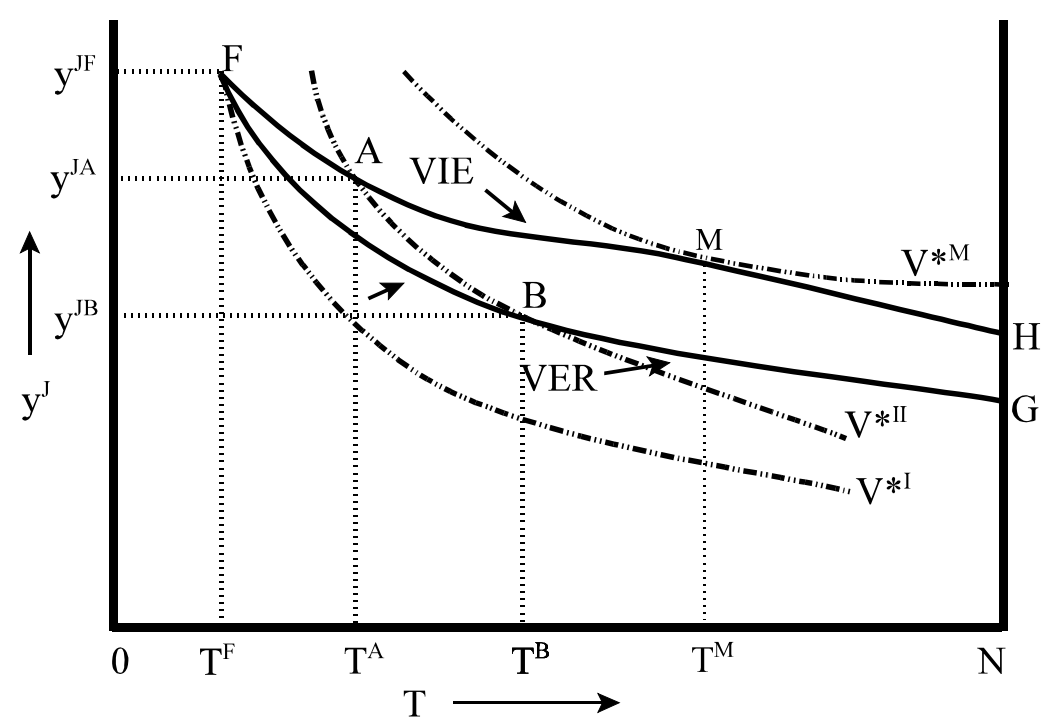

Fig. 3: VIE vs. VER for a constant value of U.S. parts exports.

Finally, Proposition 6 examines the welfare implications of the VIE and VER policies. Consumer welfare is represented by the additively separable utility function, $u(Y)+Z$, where $u(Y)$ is the utility from autos and $\mathrm{Z}$ is the utility from a tradeable numeraire good produced under pure competition using labor alone. Supposing that all income is spent and that trade is balanced with all autos sold in the U.S., it follows, letting $\Phi=\Phi\left(\mathrm{T}, \mathrm{y}^{\mathrm{J}}\right) \equiv \int_{\mathrm{T}}^{\mathrm{N}} \varphi\left(\mathrm{i}, \mathrm{y}^{\mathrm{J}}\right)$ di denote the total profit of J-suppliers, that welfare in the U.S. and Japan is respectively given by:

$$
\mathrm{W}^{\mathrm{A}} \equiv \mathrm{u}(\mathrm{Y})-\mathrm{P}(\mathrm{Y}) \mathrm{Y}+\pi^{\mathrm{A}} \text { and } \mathrm{W}^{\mathrm{J}}=\pi^{\mathrm{J}}+\Phi
$$

where $\mathrm{Y} \equiv \mathrm{y}^{\mathrm{A}}+\mathrm{y}^{\mathrm{J}}$ and $\mathrm{u}^{\prime}(\mathrm{Y})=\mathrm{P}(\mathrm{Y})$. Aggregate or world welfare is $\mathrm{W} \equiv \mathrm{W}^{\mathrm{A}}+\mathrm{W}^{\mathrm{J}}$. 
Proposition 6. Assume (17). If a VIE and VER would achieve the same value of U.S. parts exports, then,

(i) U.S. welfare is higher under the VIE than under the VER if $d W^{A} / d y^{J}>0$, and lower if $d W^{A} / d y^{J}<0$.

(ii) Japanese welfare falls, but the reduction is less under the VIE than under the VER.

(iii) If $\gamma^{*} \geq \gamma$, then world welfare falls, but the reduction is less under the VIE than under the VER.

As Proposition 6(i) shows, the U.S. is better off using a VIE than a VER to achieve a target value of U.S. parts exports if and only if the reduction in auto imports would lower U.S. welfare (i.e. iff $\mathrm{dW}^{\mathrm{A}} / \mathrm{dy}^{\mathrm{J}}$ $>0$ ). The import of fewer autos reduces consumer welfare by raising prices, but there is potentially an offsetting gain due to the shift of profits to the A-maker from the J-maker. Consumer interests tend to dominate if $\mathrm{y}^{\mathrm{A}}$ is sufficiently small relative to $\mathrm{y}^{\mathrm{J}}$ (which occurs if the A-maker has significantly higher $\operatorname{costs}^{42}$ ) and in this case, the VIE is preferred to the VER, but both policies reduce U.S. welfare. For example, for the case of linear demand, the VIE dominates ${ }^{43}$ if and only if $\mathrm{y}^{\mathrm{J}}>2 \mathrm{y}^{\mathrm{A}}$. By contrast, if the A-maker is an equal or lower cost producer at free trade (i.e. if $\gamma^{*} \leq \gamma^{\mathrm{F}}$ ) then $\mathrm{y}^{\mathrm{J}} \leq \mathrm{y}^{\mathrm{A}}$ under free trade and the VER would dominate. Japanese welfare is reduced by both policies, but as shown in Proposition 6(ii), the VIE is the better policy for Japan, since it involves less of a reduction in Japanese output and relationship-specific investment due to a smaller increase in the range of imported parts. Finally, Proposition 6(iii) shows that if the J-maker is an equal or lower cost producer (i.e. if $\gamma^{*} \geq \gamma$ for $\gamma$ evaluated under the VIE or VER) then average world production costs are increased by a reduction in $\mathrm{y}^{\mathrm{J}}$, making the VIE the preferred policy from the point of view of world welfare.

From a more general perspective, the welfare results are related to the theory of non-economic objectives developed by Bhagwati and Srinivasan (1969) and Bhagwati (1971) in a setting of pure competition. This is the idea that when variables are restricted to certain ranges by non-economic objectives, then the least cost way to achieve these objectives is to choose the policy intervention that directly affects

\footnotetext{
${ }^{42}$ This could be due to higher U.S. assembly costs. Dyer and Ouchi (1993, p53) state that for 1984, U.S. assembly costs were higher than in Japan, both as a proportion of costs (23.1\% vs $15.7 \%)$ and in total.

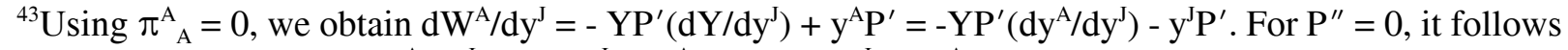
using (11) and (14) that $\mathrm{dW}^{\mathrm{A}} / \mathrm{dy}^{\mathrm{J}}=-\mathrm{P}^{\prime}\left(\mathrm{y}^{\mathrm{J}}-2 \mathrm{y}^{\mathrm{A}}\right) / 2>0$ iff $\mathrm{y}^{\mathrm{J}}>2 \mathrm{y}^{\mathrm{A}}$.
} 
the constrained variable. Although our results broadly satisfy this insight, there are significant differences caused by the presence of other distortions in the economy due to imperfect competition and incomplete contracts for relationship-specific investment. Thus from the U.S. viewpoint, a VIE is only more cost effective than a VER in raising the total value of parts exports from the U.S. if the secondary effects in other markets, such as the reduction in Japanese auto output due to the reduction in relationship-specific investment are actually undesirable.

\section{Concluding remarks}

Although a number of studies have addressed the effects of market opening policies such as VIEs directed at Japan (see the Introduction), this literature has not considered how the response to such policies is affected by the special nature of keiretsu. In this paper we develop the effects of such policies in the context of the Spencer and Qiu (2001) model, which captures some important features of long-term keiretsu supply relationships ${ }^{44}$, including relationship-specific investments and bargaining over parts' prices. There are at least three reasons for examining market opening policies in a framework that explicitly incorporates keiretsu. First, keiretsu form a large part of the manufacturing base of the Japanese economy and are responsible for a substantial share of both imports and exports ${ }^{45}$. Secondly, much of the political pressure to impose market opening policies with respect to Japan arises from complaints that trade barriers are created by keiretsu practices and forms of organization. Finally, consideration of the keiretsu structure gives rise to some richer predictions as to the effects of trade policies directed at opening the Japanese market.

In keeping with the perception of a trade barrier, relationship-specific investment causes some parts not to be imported by Japan, despite lower production costs in the U. S.. However, in contrast with the beliefs of those pushing for intervention, the model predicts that if Japan is forced to import more parts due to a VIE,

\footnotetext{
${ }^{44}$ Some other important features, such as cross-share holding, are not directly modelled. However, provided asymmetric information continues to make relationship-specific investment non-contractible, cross shareholding or even full vertical integration would not fundamentally change the nature of results.

${ }^{45}$ In 1985 , the keiretsu share of Japanese net income was around $32 \%$, accounting for about $25 \%$ of annual sales, about $44 \%$ of exports and about $68 \%$ of imports in Japan (Lawrence, 1991, p.313).
} 
this will reduce keiretsu efficiency (due to a loss of relationship-specific investment), causing a fall in production levels and in Japanese demand for parts. It is even possible that a VIE might reduce the total value of U.S. parts exports. The model also predicts that any additional parts imported by Japan in response to market opening measures such as VIEs will tend to be the least important for production, such as tail pipes and seat covers. Finally, consideration of the keiretsu form of organization has significant implications for trade policies, such as VERs or tariffs, that restrict the exports of final goods from Japan. Since relationshipspecific investment is reduced together with output, causing some keiretsu suppliers to be replaced by imports, a VER or a tariff has a market-opening effect with respect to the range of parts imported by Japan. Nevertheless, for any given value of U.S. parts exported to Japan, the VIE proves to be less costly than the VER or tariff in terms of the loss of output and consumer welfare and also with respect to the loss of Japanese profit. If the increase in consumer welfare dominates the loss of U.S. profit from greater imports of autos, then the VIE would also reduce U.S. welfare, but by less than the VER or tariff. 


\section{Appendix A}

\section{A.1. Comparative statics.}

First, using (2) to sign the terms, a useful expression for the comparative statics is

$$
\lambda^{\mathrm{i}} \equiv-\left(\mathrm{h}^{\prime}\left(\mathrm{k}^{\mathrm{i}}\right)\right)^{2} / \mathrm{h}\left(\mathrm{k}^{\mathrm{i}}\right) \mathrm{h}^{\prime \prime}\left(\mathrm{k}^{\mathrm{i}}\right)>0 \text { for } \mathrm{k}^{\mathrm{i}}>0 .
$$

From differentiation of $\mathrm{d} \phi^{\mathrm{i}} / \mathrm{dk}^{\mathrm{i}}=0$ as in $(6)$, we obtain $\mathrm{dk}^{\mathrm{i}} / \mathrm{d} \sigma^{\mathrm{i}}=-\mathrm{h}^{\prime}\left(\mathrm{k}^{\mathrm{i}}\right) / \sigma^{\mathrm{i}} \mathrm{h}^{\prime \prime}\left(\mathrm{k}^{\mathrm{i}}\right)$ and since $\mathrm{dr} / \mathrm{d} \sigma^{\mathrm{i}}=\mathrm{w}^{\mathrm{o}} \theta \mathrm{h}\left(\mathrm{k}^{\mathrm{i}}\right)[1$ $\left.+\sigma^{\mathrm{i}} \mathrm{h}^{\prime}\left(\mathrm{k}^{\mathrm{i}}\right)\left(\mathrm{dk} / \mathrm{d} \sigma^{\mathrm{i}}\right) / \mathrm{h}\left(\mathrm{k}^{\mathrm{i}}\right)\right]$ from (1), it follows, using (A1) and (2), that for $\mathrm{k}^{\mathrm{i}}>0$,

$$
\mathrm{dk}^{\mathrm{i}} / \mathrm{d} \sigma^{\mathrm{i}}=-\mathrm{h}^{\prime}\left(\mathrm{k}^{\mathrm{i}}\right) / \sigma^{\mathrm{i}} \mathrm{h}^{\prime \prime}\left(\mathrm{k}^{\mathrm{i}}\right)>0 \text { and } \mathrm{dr}^{\mathrm{i}} / \mathrm{d} \sigma^{\mathrm{i}}=\mathrm{r}^{\mathrm{i}}\left(1+\lambda^{\mathrm{i}}\right) / \sigma^{\mathrm{i}}>0 .
$$

Similarly from (6) for $\mathrm{k}^{\mathrm{i}}>0$, using $\mathrm{dr}^{\mathrm{i}} / \mathrm{dk}^{\mathrm{i}}=\mathrm{r}^{\mathrm{i}} \mathrm{h}^{\prime}\left(\mathrm{k}^{\mathrm{i}}\right) / \mathrm{h}^{\prime \prime}\left(\mathrm{k}^{\mathrm{i}}\right)$ and (A1), we obtain:

$$
\mathrm{dk}^{\mathrm{i}} / \mathrm{dy}^{\mathrm{J}}=-\mathrm{h}^{\prime}\left(\mathrm{k}^{\mathrm{i}}\right) / \mathrm{y}^{\mathrm{J}} \mathrm{h}^{\prime \prime}\left(\mathrm{k}^{\mathrm{i}}\right)>0 \text { and } \mathrm{dr}^{\mathrm{i}} / \mathrm{dy}^{\mathrm{J}}=\mathrm{r}^{\mathrm{i}} \lambda^{\mathrm{i}} / \mathrm{y}^{\mathrm{J}}>0 \text {. }
$$

Also, since $\alpha \in(0,1)$, supposing that $\mathrm{T}=\mathrm{T}\left(\mathrm{y}^{\mathrm{J}} ; \theta\right)$ satisfying (8) exists (i.e. $\left.\phi^{0}=\phi\left(0, \mathrm{y}^{\mathrm{J}} ; \theta\right) \leq 0\right)$, it follows from (8) using $\partial \phi^{\mathrm{T}} / \partial \mathrm{y}^{\mathrm{J}}=(1-\alpha)\left(\mathrm{r}^{\mathrm{T}}-\delta\right)>0$ and (7) that

$$
\mathrm{dT} / \mathrm{dy} \mathrm{J}^{\mathrm{J}}=-\left(\mathrm{r}^{\mathrm{T}}-\delta\right) \sigma^{\mathrm{T}} / \mathrm{y}^{\mathrm{J}} \mathrm{r}^{\mathrm{T}} \sigma^{\prime}(\mathrm{T})<0 .
$$

Since $\alpha \in(0,1)$, it follows from (9) that $\gamma=\gamma\left(\mathrm{T}, \mathrm{y}^{\mathrm{J}}, \theta\right)$ has partial derivatives:

$$
\partial \gamma / \partial \mathrm{T}=\alpha\left(\mathrm{r}^{\mathrm{T}}-\delta\right)>0, \partial \gamma / \partial \mathrm{y}^{\mathrm{J}}=-\alpha \int_{\mathrm{T}}^{\mathrm{N}}\left(\mathrm{dr}^{\mathrm{i}} / \mathrm{dy} \mathrm{J}^{\mathrm{J}}\right) \mathrm{di}<0 .
$$

Next examining changes in $\theta$, since $\partial \phi^{\mathrm{TF}} / \partial \theta=\mathrm{y}^{\mathrm{J}}(1-\alpha) \mathrm{r}^{\mathrm{T}} / \theta>0$ (from (8) using $\partial \phi^{\mathrm{TF}} / \partial \mathrm{k}^{\mathrm{T}}=0$ ), it follows using (7) that for $\mathrm{y}^{\mathrm{J}}$ held fixed and $\theta \in\left[\theta^{\mathrm{T}=\mathrm{N}}, \theta^{\mathrm{T}=0}\right]$,

$$
\partial \mathrm{T} / \partial \theta=-\sigma(\mathrm{T}) / \theta \sigma^{\prime}(\mathrm{T})<0 .
$$

Since $\partial \mathrm{k}^{\mathrm{i}} / \partial \theta=-\mathrm{h}^{\prime}\left(\mathrm{k}^{\mathrm{i}}\right) / \theta \mathrm{h}^{\prime \prime}\left(\mathrm{k}^{\mathrm{i}}\right)>0$ for $\mathrm{k}^{\mathrm{i}}>0$ from (6) using $\lambda^{\mathrm{i}}$ as in $(\mathrm{A} 1)$, we also obtain $\partial \mathrm{r}^{\mathrm{i}} / \partial \theta=\mathrm{w}^{\mathrm{o}} \sigma^{\mathrm{i}} \mathrm{h}\left(\mathrm{k}^{\mathrm{i}}\right)[1$ $\left.+\theta^{\mathrm{i}} \mathrm{h}^{\prime}\left(\mathrm{k}^{\mathrm{i}}\right)\left(\partial \mathrm{k}^{\mathrm{i}} / \partial \theta\right) / \mathrm{h}\left(\mathrm{k}^{\mathrm{i}}\right)\right]=\mathrm{r}^{\mathrm{i}}\left(1+\lambda^{\mathrm{i}}\right) / \theta>0$ for $\mathrm{k}^{\mathrm{i}}>0$. From $(9), \alpha>0$ and $\mathrm{T}<\mathrm{N}$, this implies

$$
\partial \gamma / \partial \theta=-\alpha \int_{\mathrm{T}}^{\mathrm{N}}\left(\partial \mathrm{r}^{\mathrm{i}} / \partial \theta\right) \mathrm{di}<0
$$

From $\gamma^{\mathrm{F}}=\gamma\left(\mathrm{T}^{\mathrm{F}}, \mathrm{y}^{\mathrm{JF}} ; \theta\right), \mathrm{T}^{\mathrm{F}}=\mathrm{T}\left(\mathrm{y}^{\mathrm{JF}}, \theta\right), \mathrm{y}^{\mathrm{JF}}=\mathrm{y}^{\mathrm{J}}\left(\gamma^{\mathrm{F}}\right)$ and (13), using (A5), (A6) and (A7) to sign expressions, we obtain $\mathrm{d} \gamma^{\mathrm{F}} / \mathrm{d} \theta=[(\partial \gamma / \partial \mathrm{T})(\partial \mathrm{T} / \partial \theta)+\partial \gamma / \partial \theta] \mathrm{H}^{0} / \mathrm{H}<0$ and using (A4), (A6), (A7) and (13), it follows that:

$$
\mathrm{dT}^{\mathrm{F}} / \mathrm{d} \theta=\left(\mathrm{dT} / \mathrm{dy}^{\mathrm{J}}\right)(\mathrm{dy} / \mathrm{d} \gamma)\left(\mathrm{d} \gamma^{\mathrm{F}} / \mathrm{d} \theta\right)+\partial \mathrm{T} / \partial \theta<0
$$

Finally, using $\gamma \equiv \gamma\left(\overline{\mathrm{T}}, \mathrm{y}^{\mathrm{J}}(\gamma) ; \theta\right),(13)$, (A5) and (A7), it follows that for $\alpha>0$ and $\mathrm{T}<\mathrm{N}$ :

$$
\begin{aligned}
& \mathrm{dy}^{\mathrm{J}} / \mathrm{d} \overline{\mathrm{T}}=\left(\mathrm{dy}^{\mathrm{J}} / \mathrm{d} \gamma\right)(\partial \gamma / \partial \overline{\mathrm{T}}) /\left[1-\left(\mathrm{dy}^{\mathrm{J}} / \mathrm{d} \gamma\right)\left(\partial \gamma / \partial \mathrm{y}^{\mathrm{J}}\right)\right]<0, \\
& \left.(\mathrm{dy} / \mathrm{d} \theta)\right|_{\mathrm{T}}=(\mathrm{dy} / \mathrm{d} \gamma)(\partial \gamma / \partial \theta) /\left[1-(\mathrm{dy} / \mathrm{d} \gamma)\left(\partial \gamma / \partial \mathrm{y}^{\mathrm{J}}\right)\right]>0 .
\end{aligned}
$$




\section{A.2. A VIE and the order of parts' imports}

Since Propositions 1 and 2 involve consideration of the import of one additional part, we use the discrete version of the model. The proofs could be adapted for the continuous model, but to have a finite impact on marginal cost, this would require consideration of the import of a range of contiguous parts.

Proof of Proposition 1. Assume $\alpha>0$. For the discrete version of the model, parts $\mathrm{i}=1,2 . . \mathrm{T}^{\mathrm{F}}-1$ are imported at free trade and marginal cost at free trade is given (analogously to (9)) by :

$$
\gamma^{\mathrm{F}}=\gamma\left(\mathrm{T}^{\mathrm{F}}, \mathrm{y}^{\mathrm{JF}}, \theta\right)=\mathrm{C}^{*}(\mathrm{~N})-\sum_{\mathrm{T}^{\mathrm{F}}}^{\mathrm{N}} \mathrm{m}^{\mathrm{i}}+\mathrm{w}^{\mathrm{o}} \text { for } \mathrm{m}^{\mathrm{i}}=\alpha\left(\mathrm{r}^{\mathrm{i}}-\delta\right) .
$$

Supposing the $\mathrm{J}$-maker imports an additional part $\mathrm{j} \in\left[\mathrm{T}^{\mathrm{F}}, \mathrm{N}\right]$, then, taking stage 1 levels of $\mathrm{k}^{\mathrm{i}}, \mathrm{y}^{\mathrm{J}}$ and $\mathrm{y}^{\mathrm{A}}$ as given, this causes a direct increase, $\mathrm{m}^{\mathrm{j}}=\mathrm{c}^{* \mathrm{j}}-\gamma^{\mathrm{j}}=\alpha\left(\mathrm{r}^{\mathrm{i}}-\delta\right)>0$, in marginal cost (see (16)). Letting $\mathrm{y}^{\mathrm{J}-\mathrm{j}}$ denote equilibrium output when part $\mathrm{j}$ is imported and taking into account induced changes in $\mathrm{k}^{\mathrm{i}}$ for $\mathrm{i} \neq \mathrm{j}$, the $\mathrm{J}$ maker's marginal cost, denoted $\gamma^{-\mathrm{j}}$, becomes:

$$
\gamma^{-\mathrm{j}} \equiv \gamma\left(\mathrm{T}^{\mathrm{F}}, \mathrm{y}^{\mathrm{J}-\mathrm{j}}, \theta\right)+\mathrm{m}^{\mathrm{j}} \text { where } \mathrm{y}^{\mathrm{J}-\mathrm{j}} \equiv \mathrm{y}^{\mathrm{J}}\left(\gamma^{-\mathrm{j}}\right) \text {. }
$$

Next, from (A10) and (A11), evaluating $\partial \gamma / \partial \mathrm{y}^{\mathrm{J}}$ for a given $\mathrm{T}^{\mathrm{F}}$ at some $\mathrm{y}^{\mathrm{J}}$ between $\mathrm{y}^{\mathrm{J}-\mathrm{j}}$ and $\mathrm{y}^{\mathrm{JF}}$, evaluating $\mathrm{dy} / \mathrm{d} \gamma^{\mathrm{j}}$ at some $\gamma$ between $\gamma^{-\mathrm{j}}$ and $\gamma^{\mathrm{F}}$ and applying the mean value theorem, we can express $\gamma\left(\mathrm{T}^{\mathrm{F}}, \mathrm{y}^{\mathrm{J}-\mathrm{j}}, \theta\right)$ $\gamma\left(\mathrm{T}^{\mathrm{F}}, \mathrm{y}^{\mathrm{JF}}, \theta\right)=\left(\partial \gamma / \partial \mathrm{y}^{\mathrm{J}}\right)\left(\mathrm{y}^{\mathrm{J}-\mathrm{j}}-\mathrm{y}^{\mathrm{JF}}\right)$ for $\mathrm{y}^{\mathrm{J}-\mathrm{j}}-\mathrm{y}^{\mathrm{JF}}=(\mathrm{dy} / \mathrm{d} \gamma)\left(\gamma^{-\mathrm{j}}-\gamma^{\mathrm{F}}\right)$. Since $\mathrm{d} \gamma / \mathrm{dy} \mathrm{y}^{\mathrm{J}}<\partial \gamma / \partial \mathrm{y}^{\mathrm{J}}<0$, we obtain $1-$ $\left(\partial \gamma / \partial \mathrm{y}^{\mathrm{J}}\right)(\mathrm{dy} / \mathrm{d} \gamma)>0$ from (13) and using (A10) and (A11), it follows that for $\alpha>0$, a commitment at stage 0 to import part $\mathrm{j} \in\left[\mathrm{T}^{\mathrm{F}}, \mathrm{N}\right]$ causes the following increase in the J-maker's marginal cost at stage 1 :

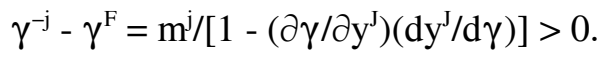

Since $\mathrm{dy}^{\mathrm{J}} / \mathrm{d} \gamma<0, \mathrm{y}^{\mathrm{J}}$ falls causing $\mathrm{k}^{\mathrm{i}}$ and $\mathrm{r}^{\mathrm{i}}$ to fall. Also, from(3), using (11), (13) and (14), we obtain, $\mathrm{d} \pi^{\mathrm{J}} / \mathrm{d} \gamma$ $=-y^{J}\left[1-p^{\prime}\left(d y^{A} / d y^{J}\right)\left(d y^{J} / d \gamma\right)\right]=-y^{J} p^{\prime}\left(2 p^{\prime}+y^{J} p^{\prime \prime}\right) / H^{0}<0$ and $d \pi^{A} / d \gamma=y^{A} p^{\prime}\left(d y^{J} / d \gamma\right)>0$.

The proof of Proposition 2 uses the following result, which we refer to as Lemma 1.

Lemma 1: The direct increase $\mathrm{m}^{j} / \mathrm{c}^{* j}$ in the J-maker's marginal cost per unit of the increase in U.S. value added from the import of part $j$ is strictly increasing in $j$ for all $j \in\left[T^{F}, N\right]$.

Proof: Letting $\sigma^{\mathrm{s}}>\sigma^{\mathrm{j}}$ for parts $\mathrm{j}, \mathrm{s} \in\left[\mathrm{T}^{\mathrm{F}}, \mathrm{N}\right]$ it follows using $\mathrm{m}^{\mathrm{j}}=\alpha\left(\mathrm{r}^{\mathrm{j}}-\mathrm{c}^{\mathrm{j}}\right)$ from $(16)$, that $\mathrm{m}^{\mathrm{s}} / \mathrm{c}^{* \mathrm{~s}}-\mathrm{m}^{\mathrm{j}} / \mathrm{c}^{* \mathrm{j}}=$ $\alpha \Omega / \mathrm{c}^{* \mathrm{j}} \mathrm{c}^{* \mathrm{~s}}>0$ iff $\Omega \equiv \mathrm{c}^{* \mathrm{j}}\left(\mathrm{r}^{\mathrm{s}}-\delta\right)-\mathrm{c}^{* \mathrm{~s}}\left(\mathrm{r}^{\mathrm{j}}-\delta\right)=\left(\mathrm{c}^{* \mathrm{~s}}-\mathrm{c}^{* \mathrm{j}}\right) \delta+\mathrm{c}^{* \mathrm{j}} \mathrm{r}^{\mathrm{s}}-\mathrm{c}^{* \mathrm{~s}} \mathrm{r}^{\mathrm{j}}>0$. Adding and subtracting $\mathrm{c}^{* \mathrm{j}} \mathrm{r}^{\mathrm{j}} \mathrm{c}^{\mathrm{s}} / \mathrm{c}^{\mathrm{j}}$ we obtain $c^{* j} r^{s}-c^{* s} r^{j}=c^{* j}\left(r^{s}-r^{j} c^{s} / c^{j}\right)-\left(c^{* s} c^{j}-c^{* j} c^{s}\right)\left(r^{j} / c^{j}\right)$. Since $\delta=c^{j}-c^{* j}=c^{s}-c^{* s}$, it follows that $c^{* s} c^{j}-$ 
$\mathrm{c}^{* \mathrm{j}} \mathrm{c}^{\mathrm{s}}=\left(\mathrm{c}^{* \mathrm{~s}}-\mathrm{c}^{* \mathrm{j}}\right) \delta$ and hence that

$$
\Omega=\left(c^{* s}-c^{* j}\right) \delta\left(1-r^{i} / c^{i}\right)+c^{* j}\left(r^{s}-r^{j} c^{s} / c^{j}\right) .
$$

Using $\mathrm{r}^{\mathrm{i}}=\mathrm{w}^{\mathrm{o}} \sigma^{\mathrm{i}} \theta \mathrm{h}\left(\mathrm{k}^{\mathrm{i}}\right)$ and $\sigma^{\mathrm{i}}=\mathrm{c}^{\mathrm{i}} / \mathrm{C}(\mathrm{N})$, we have $\mathrm{r}^{\mathrm{s}}-\mathrm{r}^{\mathrm{j}} \mathrm{c}^{\mathrm{s}} / \mathrm{c}^{\mathrm{j}}=\mathrm{w}^{\mathrm{o}} \sigma^{\mathrm{s}} \theta\left(\mathrm{h}\left(\mathrm{k}^{\mathrm{s}}\right)-\mathrm{h}\left(\mathrm{k}^{\mathrm{j}}\right)\right)>0$ for $\sigma^{\mathrm{s}}>\sigma^{\mathrm{j}}$ and since $\mathrm{c}^{\mathrm{i}}-$ $\mathrm{r}^{\mathrm{i}}>0$ (no free lunch from (1)), we obtain $\Omega>0$ from (A13).

Proof of Proposition 2: Since profit, $\pi^{\mathrm{J}}=\pi^{\mathrm{J}}(\gamma)=\mathrm{y}^{\mathrm{J}}(\mathrm{P}(\mathrm{y})-\gamma)$ for $\mathrm{y}^{\mathrm{J}}=\mathrm{y}^{\mathrm{J}}(\gamma)$, depends only on $\gamma$ and $\mathrm{d} \pi^{\mathrm{J}} / \mathrm{d} \gamma$ $<0$, the J-maker imports additional parts to minimize the increase in $\gamma$ subject to achieving the VIE target. Thus the first additional imported part $\mathrm{j} \in\left[\mathrm{T}^{\mathrm{F}}, \mathrm{N}\right]$ is chosen to minimize the increase in marginal cost, $\gamma^{-\mathrm{j}}$ $\gamma^{\mathrm{F}}$, per unit of the contribution of part $\mathrm{j}$ to achieving the VIE target.

(i) For a content VIE, since part $\mathrm{j} \in\left[\mathrm{T}^{\mathrm{F}}, \mathrm{N}\right]$ contributes $\mathrm{c}^{* \mathrm{j}}$ towards the target, it follows, using (A12), that part $\mathrm{j}$ is chosen to minimize

$$
\mathrm{M}^{\mathrm{j}} \equiv\left(\gamma^{-\mathrm{j}}-\gamma^{\mathrm{F}}\right) / \mathrm{c}^{* \mathrm{j}}=\left(\mathrm{m}^{\mathrm{j}} / \mathrm{c}^{* \mathrm{j}}\right) /\left[1-\left(\partial \gamma / \partial \mathrm{y}^{\mathrm{J}}\right)(\mathrm{dy} / \mathrm{d} \gamma)\right]
$$

where $\partial \gamma / \partial \mathrm{y}^{\mathrm{J}}$ is evaluated holding $\mathrm{T}=\mathrm{T}^{\mathrm{F}}$ fixed. Since from Lemma 1 and (A14), $\mathrm{M}^{\mathrm{j}}$ is strictly increasing in $\mathrm{j}$, the first part imported is $\mathrm{j}=\mathrm{T}^{\mathrm{F}}$, which has the lowest cost-share in $\left[\mathrm{T}^{\mathrm{F}}, \mathrm{N}\right]$. If the VIE is not satisfied, the same argument can be repeated with respect to a second part, $\mathrm{j} \in\left[\mathrm{T}^{\mathrm{F}+1}, \mathrm{~N}\right]$, but with part $\mathrm{j}=\mathrm{T}^{\mathrm{F}}$ now included in the initial import set. In (A14), $\partial \gamma / \partial \mathrm{y}^{\mathrm{J}}$ is then evaluated holding $\mathrm{T}$ fixed at $\mathrm{T}^{\mathrm{F}}+1$.

(ii). For market-share VIEs, denoting the free trade levels of U.S. and Japanese content (at marginal cost) by $\mathrm{v}^{* \mathrm{~F}} \equiv \mathrm{v}^{*}\left(\mathrm{~T}^{\mathrm{F}}\right) \equiv \sum_{1}^{\mathrm{T}^{\mathrm{F}}-1} \mathrm{c}^{* \mathrm{i}}$ and $\mathrm{v}^{\mathrm{F}} \equiv \mathrm{v}\left(\mathrm{T}^{\mathrm{F}}\right) \equiv \sum_{\mathrm{T}^{\mathrm{F}}}^{\mathrm{N}} \mathrm{c}^{\mathrm{i}}$ respectively, the corresponding U.S. market share is $\mathrm{S}^{\mathrm{F}} \equiv \mathrm{V}^{* \mathrm{~F}} / \omega^{\mathrm{F}}$ where $\omega^{\mathrm{F}} \equiv \mathrm{v}^{* \mathrm{~F}}+\mathrm{v}^{\mathrm{F}}$. If just one part $\mathrm{j} \notin \Delta^{\mathrm{F}}$ is imported in addition to $\Delta^{\mathrm{F}}$, the U.S. market share becomes $S^{\mathrm{F}+\mathrm{j}} \equiv\left(\mathrm{v}^{* \mathrm{~F}}+\mathrm{c}^{* \mathrm{j}}\right) /\left(\omega^{\mathrm{F}}-\delta\right)$ and the contribution towards satisfying the VIE is $\mathrm{S}^{\mathrm{F}+\mathrm{j}}-\mathrm{S}^{\mathrm{F}}$. Consequently, $\operatorname{part} \mathrm{j} \in\left[\mathrm{T}^{\mathrm{F}}, \mathrm{N}\right]$ is chosen so as to minimize:

$$
\mathrm{M}^{\mathrm{Sj}} \equiv\left(\gamma^{-\mathrm{j}}-\gamma^{\mathrm{F}}\right) /\left(\mathrm{S}^{\mathrm{F}+\mathrm{j}}-\mathrm{S}^{\mathrm{F}}\right) .
$$

Using $M^{j} \equiv\left(\gamma^{-j}-\gamma^{\mathrm{F}}\right) / \mathrm{c}^{* j}$ from (A14), we can express (A15) in the form $\mathrm{M}^{\mathrm{Sj}}=\mathrm{M}^{\mathrm{j}} \mathrm{X}^{\mathrm{Sj}}$ for $\mathrm{X}^{\mathrm{Sj}} \equiv \mathrm{c}^{* j} /\left(\mathrm{S}^{\mathrm{F}+\mathrm{j}}-\mathrm{S}^{\mathrm{F}}\right)$ and since $S^{\mathrm{F}+\mathrm{j}}-\mathrm{S}^{\mathrm{F}}=\left(\mathrm{v}^{* \mathrm{~F}}+\mathrm{c}^{* \mathrm{j}}\right) /\left(\omega^{\mathrm{F}}-\delta\right)-\mathrm{v}^{* \mathrm{~F}} / \omega^{\mathrm{F}}=\left(\mathrm{c}^{* \mathrm{j}} \omega^{\mathrm{F}}+\mathrm{v}^{* \mathrm{~F}} \delta\right) / \omega^{\mathrm{F}}\left(\omega^{\mathrm{F}}-\delta\right)$, we obtain

$$
\mathrm{X}^{\mathrm{Sj}}=\omega^{\mathrm{F}}\left(\omega^{\mathrm{F}}-\delta\right) /\left[\omega^{\mathrm{F}}+\mathrm{v}^{* \mathrm{~F}}\left(\delta / \mathrm{c}^{* \mathrm{j}}\right)\right]>0 .
$$

Next, letting part s satisfy $\sigma^{\mathrm{s}}>\sigma^{\mathrm{j}}$ for $\mathrm{j}, \mathrm{s} \in\left[\mathrm{T}^{\mathrm{F}}, \mathrm{N}\right]$, it follows that the J-maker will choose parts $\mathrm{j}$ in increasing order of cost-share on $j \in\left[T^{F}, N\right]$ if and only if $M^{S s}-M^{S j}=\left(M^{s}-M^{j}\right) X^{S s}+M^{j}\left(X^{S s}-X^{S j}\right)>0$. Since $X^{S s}-X^{S j}$ 
$>0$ from (A16) and $c^{* s}>c^{* j}$ for $s>j$ and $M^{s}-M^{j}>0$ from the proof of (i), the result follows.

(iii) For total-value VIEs, letting $\mathrm{V}^{* \mathrm{~F}} \equiv \mathrm{V}^{* \mathrm{~F}} \mathrm{y}^{\mathrm{J}}\left(\gamma^{\mathrm{F}}\right)$ denote the total value of U.S. exports at free trade, if part $\mathrm{j} \notin \Delta^{\mathrm{F}}$ is imported in addition to $\Delta^{\mathrm{F}}$, the total value of U.S. exports becomes $\mathrm{V}^{* \mathrm{~F}+\mathrm{j}}=\left(\mathrm{v}^{* \mathrm{~F}}+\mathrm{c}^{* \mathrm{j}}\right) \mathrm{y}^{\mathrm{J}}\left(\gamma^{-\mathrm{j}}\right)$ and the contribution towards satisfying the VIE is $\mathrm{V}^{* \mathrm{~F}+\mathrm{j}}-\mathrm{V}^{* \mathrm{~F}}$. Hence part $\mathrm{j} \in\left[\mathrm{T}^{\mathrm{F}}, \mathrm{N}\right]$ is chosen to minimize $\mathrm{M}^{\mathrm{Vj}}$ $\equiv\left(\gamma^{-\mathrm{j}}-\gamma^{\mathrm{F}}\right) /\left(\mathrm{V}^{* \mathrm{~F}+\mathrm{j}}-\mathrm{V}^{* \mathrm{~F}}\right)$. Using $\mathrm{d}^{2} \mathrm{y}^{\mathrm{J}} /(\mathrm{d} \gamma)^{2}=0$ from (13) and (11) for $\mathrm{P}^{\prime \prime}(\mathrm{Y})=0$ (linear demand), we have $\mathrm{y}$ ${ }^{\mathrm{J}}\left(\gamma^{-\mathrm{j}}\right)-\mathrm{y}^{\mathrm{J}}\left(\gamma^{\mathrm{F}}\right)=(\mathrm{dy} / \mathrm{d} \gamma)\left(\gamma^{-\mathrm{j}}-\gamma^{\mathrm{F}}\right)$ and, using $(18 \mathrm{~A})$, we obtain $\mathrm{M}^{\mathrm{Vj}} \equiv\left(\gamma^{-\mathrm{j}}-\gamma^{\mathrm{F}}\right) /\left(\mathrm{V}^{* \mathrm{~F}+\mathrm{j}}-\mathrm{V}^{* \mathrm{~F}}\right)=1 /\left[\mathrm{v}^{* \mathrm{~F}}(\mathrm{dy} / \mathrm{d} \gamma)\right.$ $\left.+y^{\mathrm{J}}\left(\gamma^{-\mathrm{j}}\right) / \mathrm{M}^{\mathrm{j}}\right]$. Since $\mathrm{M}^{\mathrm{s}}>\mathrm{M}^{\mathrm{j}}$ from the proof of (i) and $\mathrm{y}^{\mathrm{J}}\left(\gamma^{-s}\right)<\mathrm{y}^{\mathrm{J}}\left(\gamma^{-\mathrm{j}}\right)$, it follows that $\mathrm{y}^{\mathrm{J}}\left(\gamma^{-\mathrm{s}}\right) / \mathrm{M}^{\mathrm{s}}<\mathrm{y}^{\mathrm{J}}\left(\gamma^{-\mathrm{j}}\right) / \mathrm{M}^{\mathrm{j}}$ and hence $\mathrm{M}^{\mathrm{Vs}}>\mathrm{M}^{\mathrm{Vj}}$, proving the result.

\section{A.3. Effects of trade policies}

Proof of Proposition 3. Since trade in parts is not restricted by a VER or tariff, parts are imported in the same order (i.e. increasing cost-share) as under free trade. Since $d k^{i} / d \bar{y}^{J}>0$ for $k^{i}>0$ from $(A 3)$ and $d T\left(\bar{y}^{J}\right) / d \bar{y}^{J}<$ 0 from (A4), a reduction in $\bar{y}^{\mathrm{J}}$ due to a VER reduces $\mathrm{k}^{\mathrm{i}}$ and increases $\Delta^{\mathrm{y}}$ leading to a rise in U.S. content per auto and market-share in the same way as for a VIE. For the tariff, from $\tau=\gamma\left(T, y^{\mathrm{J}} ; \theta\right)+\mathrm{t}$ for $\mathrm{y}^{\mathrm{J}}=\mathrm{y}^{\mathrm{J}}(\tau)$ and $\mathrm{T}=\mathrm{T}\left(\mathrm{y}^{\mathrm{J}}(\tau), \theta\right)$, it follows, using $(13)$ that $\mathrm{d} \tau / \mathrm{dt}=1 /\left[1-\left(\mathrm{d} \gamma / \mathrm{dy}^{\mathrm{J}}\right)\left(\mathrm{dy}^{\mathrm{J}} / \mathrm{d} \gamma\right)\right]>0$ and $\mathrm{dy}^{\mathrm{J}} / \mathrm{dt}=(\mathrm{dy} / \mathrm{d} \tau)(\mathrm{d} \tau / \mathrm{dt})<$ 0. Setting $\mathrm{y}^{\mathrm{J}}(\tau)=\overline{\mathrm{y}}^{\mathrm{J}}$, the results follow for the tariff as for the VER.

Proof of Proposition 4. We first show that if the VIE is binding at free trade (i.e. if $\bar{T}>T^{\mathrm{F}}=\mathrm{T}\left(\mathrm{y}^{\mathrm{J}}\left(\gamma^{\mathrm{F}}\right)\right.$ ), then the marginal supplier producing part $i=\bar{T}$, earns a strictly positive profit. This requires that $\bar{T}>\mathrm{T}\left(\mathrm{y}^{\mathrm{J}}\left(\gamma^{\mathrm{T}}\right)\right)$ for $\gamma^{T}=\gamma\left(y^{J}\left(\gamma^{T}\right), \bar{T}\right)$, which is not obvious since the loss of investment makes $y^{\mathrm{J}}\left(\gamma^{\mathrm{T}}\right)<\mathrm{y}^{\mathrm{J}}\left(\gamma^{\mathrm{F}}\right)$ and $\mathrm{T}\left(\mathrm{y}^{\mathrm{J}}\left(\gamma^{\mathrm{T}}\right)\right)$ $>\mathrm{T}^{\mathrm{F}}$. Since $\mathrm{dT} / \mathrm{d} \overline{\mathrm{T}}=\left(\mathrm{dT} / \mathrm{dy}{ }^{\mathrm{J}}\right)(\mathrm{dy} / \mathrm{d} \gamma)\left(\mathrm{d} \gamma^{\mathrm{T}} / \mathrm{d} \overline{\mathrm{T}}\right)$ using $\mathrm{d} \gamma^{\mathrm{T}} / \mathrm{d} \overline{\mathrm{T}}=(\partial \gamma / \partial \overline{\mathrm{T}}) /\left[1-\left(\partial \gamma / \partial \mathrm{y}^{\mathrm{J}}\right)(\mathrm{dy} / \mathrm{d} \gamma)\right]$, we obtain $\overline{\mathrm{T}}$ $>\mathrm{T}\left(\mathrm{y}^{\mathrm{J}}\left(\gamma^{\mathrm{T}}\right)\right)$ if $\mathrm{dT}\left(\mathrm{y}^{\mathrm{J}}\left(\gamma^{\mathrm{T}}\right)\right) / \mathrm{d} \overline{\mathrm{T}}<1$, which holds if $\left(\mathrm{dT} / \mathrm{dy}^{\mathrm{J}}\right)(\mathrm{dy} / \mathrm{d} \gamma)(\partial \gamma / \partial \overline{\mathrm{T}})<1-\left(\partial \gamma / \partial \mathrm{y}^{\mathrm{J}}\right)(\mathrm{dy} / \mathrm{d} \gamma)$. This last expression reduces to $1-\left(d \gamma / d y^{J}\right)\left(d y^{J} / d \gamma\right)>0$, which is the stability condition (13). Since for a VER (or tariff with $\left.\mathrm{y}^{\mathrm{J}}(\tau)=\bar{y}^{\mathrm{J}}\right)$, the parts market is not constrained, we obtain:

$$
\phi\left(\overline{\mathrm{T}}, \mathrm{y}^{\mathrm{J}}\left(\gamma^{\mathrm{T}}\right)\right)>0 \text { and } \phi\left(\mathrm{T}\left(\overline{\mathrm{y}}^{\mathrm{J}}\right), \overline{\mathrm{y}}^{\mathrm{J}}\right)=0 .
$$

(i) To show $\overline{\mathrm{T}}>\mathrm{T}\left(\overline{\mathrm{y}}^{\mathrm{J}}\right)$ for $\mathrm{y}^{\mathrm{J}}\left(\gamma^{\mathrm{T}}\right)=\overline{\mathrm{y}}^{\mathrm{J}}$, since $\mathrm{dy} / \mathrm{d} \overline{\mathrm{T}}<0$ from (A9), it follows that for any $\overline{\mathrm{y}}^{\mathrm{J}} \leq \mathrm{y}^{\mathrm{J}}\left(\gamma^{\mathrm{F}}\right)$, part $\mathrm{i}=$ $\overline{\mathrm{T}}$, satisfying $\overline{\mathrm{y}}^{\mathrm{J}}=\mathrm{y}^{\mathrm{J}}\left(\gamma^{\mathrm{T}}\right)$, is unique. Since $\mathrm{d} \phi\left(\mathrm{i}, \mathrm{y}^{\mathrm{J}}\right) / \mathrm{di}>0$ from (7), it follows, setting $\overline{\mathrm{y}}^{\mathrm{J}}=\mathrm{y}^{\mathrm{J}}\left(\gamma^{\mathrm{T}}\right)$ in (A17), that $\overline{\mathrm{T}}$ $>\mathrm{T}\left(\overline{\mathrm{y}}^{\mathrm{J}}\right)$. (ii) To show $\mathrm{y}^{\mathrm{J}}\left(\gamma^{\mathrm{T}}\right)>\overline{\mathrm{y}}^{\mathrm{J}}$ if $\overline{\mathrm{T}}=\mathrm{T}\left(\overline{\mathrm{y}}^{\mathrm{J}}\right)$, since $\mathrm{dT}\left(\overline{\mathrm{y}}^{\mathrm{J}}\right) / \mathrm{d} \overline{\mathrm{y}}^{\mathrm{J}}<0$ for $\overline{\mathrm{y}}^{\mathrm{J}} \geq \mathrm{y}\left(\gamma^{\mathrm{F}}\right)$ from Proposition 3, it follows 
that for any $\bar{T} \in\left[T^{F}, N\right]$, there exists a unique value of $\bar{y}^{\mathrm{J}}$ such that $\overline{\mathrm{T}}=\mathrm{T}\left(\overline{\mathrm{y}}^{\mathrm{J}}\right)$. Since $\mathrm{d} \phi\left(\mathrm{i}, \mathrm{y}^{\mathrm{J}}\right) / \mathrm{dy} \mathrm{y}^{\mathrm{J}}>0$, it follows, setting $\mathrm{T}\left(\overline{\mathrm{y}}^{\mathrm{J}}\right)=\overline{\mathrm{T}}$ in (A17) that $\mathrm{y}^{\mathrm{J}}\left(\gamma^{\mathrm{T}}\right)>\overline{\mathrm{y}}^{\mathrm{J}}$. (iii) To show that $\mathrm{T}\left(\overline{\mathrm{y}}^{\mathrm{J}}\right)>\overline{\mathrm{T}}$ and $\overline{\mathrm{y}}^{\mathrm{J}}<\mathrm{y}^{\mathrm{J}}\left(\gamma^{\mathrm{T}}\right)$ for $\mathrm{V}^{* \mathrm{y}}=\mathrm{V}^{*}$ ${ }^{\mathrm{T}}$, we have $\mathrm{T}\left(\overline{\mathrm{y}}^{\mathrm{J}}\right) \neq \overline{\mathrm{T}}$ since if $\mathrm{T}\left(\overline{\mathrm{y}}^{\mathrm{J}}\right)=\overline{\mathrm{T}}$, then $\mathrm{V}^{* \mathrm{y}}<\mathrm{V}^{* \mathrm{~T}}$ from Proposition 4(ii). To rule out $\mathrm{T}\left(\overline{\mathrm{y}}^{\mathrm{J}}\right)<\overline{\mathrm{T}}$, suppose initially that $\mathrm{T}\left(\overline{\mathrm{y}}^{\mathrm{J}}\right)=\overline{\mathrm{T}}$. Since $\mathrm{dT} / \mathrm{d} \overline{\mathrm{y}}^{\mathrm{J}}<0$ from (A4), we must raise either $\overline{\mathrm{T}}$ or $\overline{\mathrm{y}}^{\mathrm{J}}$ to obtain $\mathrm{T}\left(\overline{\mathrm{y}}^{\mathrm{J}}\right)<\overline{\mathrm{T}}$, which, using $\mathrm{dV}^{* \mathrm{~T}} / \mathrm{d} \overline{\mathrm{T}}>0$ and $\mathrm{dV}^{* \mathrm{y}} / \mathrm{dy}^{\mathrm{J}}<0$ from (17), again implies $\mathrm{V}^{* \mathrm{y}}<\mathrm{V}^{* \mathrm{~T}}$. Letting $\mathrm{V}^{*}\left(\mathrm{~T}, \mathrm{y}^{\mathrm{J}}\right)=\mathrm{v}^{*}(\mathrm{~T}) \mathrm{y}^{\mathrm{J}}$, it follows using the mean value theorem, that $V^{* T}-V^{* y}=\left(\partial V^{*} / \partial T\right)\left(\bar{T}-T\left(\bar{y}^{J}\right)\right)+\left(\partial V^{*} / d y^{J}\right)\left(y^{J}\left(\gamma^{T}\right)-\bar{y}^{J}\right)$, where $\partial \mathrm{V}^{*} / \partial \mathrm{T}=\mathrm{c}^{*}(\mathrm{~T}) \mathrm{y}^{\mathrm{J}}>0$ and $\partial \mathrm{V} * / \mathrm{dy} \mathrm{J}^{\mathrm{J}}=\mathrm{v}^{*}(\mathrm{~T})>0$ for intermediate values of $\mathrm{y}^{\mathrm{J}}$ and $\mathrm{T}$. Since $\overline{\mathrm{T}}-\mathrm{T}\left(\overline{\mathrm{y}}^{\mathrm{J}}\right)<0$ at $\mathrm{V}^{* \mathrm{~T}}$ $=\mathrm{V}^{* \mathrm{y}}$, this implies $\mathrm{y}^{\mathrm{J}}\left(\gamma^{\mathrm{T}}\right)>\bar{y}^{\mathrm{J}}$.

Proof of Proposition 5. Letting $\pi^{\mathrm{Jy}}=\pi^{\mathrm{J}}\left(\overline{\mathrm{y}}^{\mathrm{J}}, \mathrm{T}\left(\overline{\mathrm{y}}^{\mathrm{J}}\right)\right)$ and $\pi^{\mathrm{JT}}=\pi^{\mathrm{J}}\left(\mathrm{y}^{\mathrm{J}}\left(\boldsymbol{\gamma}^{\mathrm{T}}\right), \overline{\mathrm{T}}\right)$ represent $\mathrm{J}$-maker profit under the VER and VIE respectively and using the mean value theorem, it follows that $\pi^{\mathrm{Jy}}-\pi^{\mathrm{JT}}=\left(\partial \pi^{\mathrm{J}} / \partial \mathrm{y}^{\mathrm{J}}\right)\left(\overline{\mathrm{y}}^{\mathrm{J}}-\mathrm{y}^{\mathrm{J}}\left(\gamma^{\mathrm{T}}\right)\right)$ $+\left(\partial \pi^{\mathrm{J}} / \partial \mathrm{T}\right)\left(\mathrm{T}\left(\overline{\mathrm{y}}^{\mathrm{J}}\right)-\overline{\mathrm{T}}\right)$, where, using $\pi_{\mathrm{J}}^{\mathrm{J}} \geq 0\left(\right.$ from $(10)$ and $\left.\overline{\mathrm{y}}^{\mathrm{J}} \leq \mathrm{y}^{\mathrm{J}}(\gamma)\right)$, we obtain $\partial \pi^{\mathrm{J}} / \partial \mathrm{y}^{\mathrm{J}}=\pi_{\mathrm{J}}^{\mathrm{J}}+\mathrm{y}^{\mathrm{J}}\left[\mathrm{p}^{\prime}\left(\mathrm{dy}^{\mathrm{A}} / \mathrm{dy} \mathrm{y}^{\mathrm{J}}\right)\right.$ $\left.-\left(\partial \gamma / \partial y^{J}\right)\right]>0$ for strategic substitutes. Since $\partial \pi^{\mathrm{J}} / \partial \mathrm{T}=-\mathrm{y}^{\mathrm{J}}(\partial \gamma / \partial \mathrm{T})<0$, it follows using Proposition 4(iii) that $\pi^{\mathrm{Jy}}-\pi^{\mathrm{JT}}<0$ for $\mathrm{V}^{* \mathrm{~T}}=\mathrm{V}^{* \mathrm{y}}$. A tariff would reduce $\pi^{\mathrm{J}}$ by more than a VER.

Proof of Proposition 6. (i) Since $\mathrm{W}^{\mathrm{A}}=\mathrm{W}^{\mathrm{A}}\left(\overline{\mathrm{y}}^{\mathrm{J}}\right)$ for a VER and $\mathrm{W}^{\mathrm{A}}=\mathrm{W}^{\mathrm{A}}\left(\mathrm{y}^{\mathrm{J}}\left(\gamma^{\mathrm{T}}\right)\right)$ for a VIE, using the mean value theorem, we obtain $\mathrm{W}^{\mathrm{A}}\left(\overline{\mathrm{y}}^{\mathrm{J}}\right)-\mathrm{W}^{\mathrm{A}}\left(\mathrm{y}^{\mathrm{J}}\left(\gamma^{\mathrm{T}}\right)\right)=\left(\mathrm{dW}^{\mathrm{A}} / \mathrm{dy} \mathrm{y}^{\mathrm{J}}\right)\left(\overline{\mathrm{y}}^{\mathrm{J}}-\mathrm{y}^{\mathrm{J}}\left(\gamma^{\mathrm{T}}\right)\right)$, where $\mathrm{dW}^{\mathrm{A}} / \mathrm{dy}$ is evaluated at some $\mathrm{y}^{\mathrm{J}}$ between $\overline{\mathrm{y}}^{\mathrm{J}}$ and $\mathrm{y}^{\mathrm{J}}\left(\boldsymbol{\gamma}^{\mathrm{T}}\right)$. Since $\overline{\mathrm{y}}^{\mathrm{J}}-\mathrm{y}^{\mathrm{J}}\left(\boldsymbol{\gamma}^{\mathrm{T}}\right)<0$ for $\mathrm{V}^{* \mathrm{y}}=\mathrm{V}^{* \mathrm{~T}}$ from Proposition 4(iii), we obtain $\mathrm{W}^{\mathrm{A}}\left(\overline{\mathrm{y}}^{\mathrm{J}}\right)$ $\mathrm{W}^{\mathrm{A}}\left(\mathrm{y}^{\mathrm{J}}\left(\gamma^{\mathrm{T}}\right)<0\right.$ if $\mathrm{dW}^{\mathrm{A}} / \mathrm{dy}^{\mathrm{J}}>0$ and $\mathrm{W}^{\mathrm{A}}\left(\overline{\mathrm{y}}^{\mathrm{J}}\right)-\mathrm{W}^{\mathrm{A}}\left(\mathrm{y}^{\mathrm{J}}\left(\gamma^{\mathrm{T}}\right)>0\right.$ if $\mathrm{dW}^{\mathrm{A}} / \mathrm{dy} \mathrm{y}^{\mathrm{J}}<0$. (ii). To show that $\mathrm{W}^{\mathrm{J}}=\pi^{\mathrm{J}}+\Phi$ is lower under a VER than a VIE for $\mathrm{V}^{* \mathrm{y}}=\mathrm{V}^{* \mathrm{~T}}$, since $\pi^{\mathrm{J}}$ is lower from Proposition 5, it remains to show that $\Phi$ is lower. Since $\partial \Phi / \mathrm{dy}^{\mathrm{J}}=\int_{\mathrm{T}}{ }^{\mathrm{N}}\left(\partial \phi^{\mathrm{i}} / \partial \mathrm{y}^{\mathrm{J}}\right) \mathrm{di}>0$ and $\partial \Phi / \mathrm{dT}=-\phi^{\mathrm{T}}<0$ the result follows using Proposition 4(iii). (iii) From (18) and (3), world welfare, $\mathrm{W} \equiv \mathrm{W}^{\mathrm{A}}+\mathrm{W}^{\mathrm{J}}$, can be expressed as $\mathrm{W}\left(\mathrm{y}^{\mathrm{J}}, \mathrm{T}\right)=\mathrm{u}(\mathrm{Y})-\gamma^{\mathrm{w}} \mathrm{Y}+\Phi$ where $\gamma^{\mathrm{w}} \equiv \gamma^{*}\left(\mathrm{y}^{\mathrm{A}} / \mathrm{Y}\right)+\gamma\left(\mathrm{y}^{\mathrm{J}} / \mathrm{Y}\right)$ represents the average world cost of production. Since $\mathrm{dy}^{\mathrm{A}} / \mathrm{dy}^{\mathrm{J}}<0$ from (14), we obtain $d\left(y^{J} / Y\right) / d y^{J}>0$ and, using (A5), it follows that for $\gamma^{*} \geq \gamma, \partial \gamma^{w} / \partial y^{J}=-\left(\gamma^{*}-\gamma\right) d\left(y^{J} / Y\right) / d y^{J}+$ $\left(y^{J} / Y\right)\left(\partial \gamma / \partial y^{J}\right)<0$. Since $d Y / d y^{J}>0$ and $\partial \Phi / \partial y^{J}>0$, this implies $\partial W / \partial y^{J}=\left(P-\gamma^{w}\right)\left(d Y / d y^{J}\right)-Y\left(\partial \gamma^{w} / \partial y^{J}\right)+$ $\partial \Phi / \partial \mathrm{y}^{\mathrm{J}}>0$ for $\gamma^{*} \geq \gamma$. Also, using $\partial \gamma^{\mathrm{w}} / \partial \mathrm{T}=\left(\mathrm{y}^{\mathrm{J}} / \mathrm{Y}\right)(\partial \gamma / \partial \mathrm{T})>0$, we obtain $\partial \mathrm{W} / \partial \mathrm{T}=-\mathrm{Y}\left(\partial \gamma^{\mathrm{w}} / \partial \mathrm{T}\right)-\phi^{\mathrm{T}}<0$. Using the mean value theorem and Proposition 4(iii), it then follows that $\mathrm{W}\left(\overline{\mathrm{y}}^{\mathrm{J}}, \mathrm{T}\left(\overline{\mathrm{y}}^{\mathrm{J}}\right)\right)-\mathrm{W}\left(\mathrm{y}^{\mathrm{J}}\left(\gamma^{\mathrm{T}}\right), \overline{\mathrm{T}}\right)=$ $\left(\partial \mathrm{W} / \partial \mathrm{y}^{\mathrm{J}}\right)\left(\overline{\mathrm{y}}^{\mathrm{J}}-\mathrm{y}^{\mathrm{J}}\left(\gamma^{\mathrm{T}}\right)\right)+(\partial \mathrm{W} / \partial \mathrm{T})\left(\mathrm{T}\left(\overline{\mathrm{y}}^{\mathrm{J}}\right)-\overline{\mathrm{T}}\right)<0$ for $\gamma^{*} \geq \gamma$ 


\section{References}

Aoki, M., 1988. Information, Incentives and Bargaining in the Japanese Economy. Cambridge University Press.

Asanuma, B., 1989. Manufacturer-supplier relationships in Japan and the concept of relation-specific skill. Journal of the Japanese and International Economies 3, 1-30.

Belderbos, R., Sleuwaegen, L., 1998. Tariff jumping DFI and export substitution: Japanese electronic firms in Europe. International Journal of Industrial Organization 16(5), 601-638.

Bernier, L., Borrus, A., Bremner, B., Holstein, W.J., 1995. Rougher trade: The U.S.-Japan chasm widens. Business Week, July 17, 16-18.

Bhagwati, J.N., Srinivasan, T.N., 1969. Optimal intervention to achieve non-economic objectives. Review of Economic Studies 36(1), 27-38.

Bhagwati, J.N., 1971. Generalized theory of distortions and welfare. In: Bhagwati, J.N., Mundell, R.A., Jones, R.W., Vanek, J. (Eds.), Trade, Balance of Payments and Growth: Papers in International Economics in Honor of Charles C. Kindleberger. Amsterdam: North-Holland, Chapter 4, 69-90.

Bhagwati, J.N., 1987. VERs, quid pro quo DFI and VIEs: Political-economy-theoretic analysis. International Economic Journal,1-14.

Bjorksten, N., 1994. Voluntary import expansions and voluntary export restraints in an oligopoly model with capacity constraints. Canadian Journal of Economics, 446-457.

Branstetter, L., 2000. Vertical keiretsu and knowledge spillovers in Japanese manufacturing: An empirical assessment. The Journal of the Japanese and International Economies 14, 73-104.

Church, G. J., 1995. Launch of an economic cold war. TIME Domestic, 146, July 3.

Cronshaw M.B., Markusen, J.R., 1995. The theory and consequences of results-oriented trade policy. In: Deardorff, A.V., Levinsohn, J., Stern, R.M. (Eds.), New Directions in Trade Theory. Ann Arbor: University of Michigan Press, 295 - 326.

Dodwell Marketing Consultants, 1990. The Structure of the Japanese Auto Parts Industry. Tokyo: Dodwell Marketing Consultants.

Dyer, J.H., Ouchi, W.G., 1993. Japanese-style partnerships: Giving companies a competitive edge. Sloan Management Review 35(1), 51-63.

FEER (Far Eastern Economic Review), 1993. Reject managed trade. Far Eastern Economic Review 4, November, p.2.

Fung, K.C., 1991. Characteristics of Japanese industrial groups and their potential impact on U.S.-Japan trade. In: Baldwin, R., (Ed.), Empirical Studies of Commercial Policy. Chicago: University of Chicago Press, 137-168.

Greaney, T.M., 1996. Import now! An analysis of market-share voluntary import expansions (VIEs). Journal of International Economics 40(1-2), 149-163. 
Head, K., Ries J., Swenson, D., 1995. Agglomeration benefits and location choice: Evidence from Japanese manufacturing investments in the United States. Journal of International Economics 38, 223-247.

Irwin, D.A., 1996. The U.S.-Japan semiconductor trade conflict. In: Krueger, A.O., (Eds.), The Political Economy of Trade Protection, Chapter 1. Chicago: The University of Chicago Press.

Krishna, K., 1989. Trade restrictions as facilitating practices. Journal of International Economics 26, 251270.

Krishna, K., Morgan, J., 1998. Implementing results-oriented trade policies: The case of the US-Japanese auto parts dispute. European Economic Review 42(8), 1443-1467.

Krishna, K., Roy, S., Thursby, M., 1998. Implementing market access. Review of International Economics 6(4), 529-544.

Krishna, K., Roy, S., Thursby, M., 2001. Can subsidies for MARs be procompetitive. Canadian Journal of Economics, 34(1), 212-224.

Lawrence, R. Z., 1991. Efficient or exclusionist? The import behavior of Japanese corporate groups. Brookings Papers on Economic Activity, 311-330.

Levinsohn, J., 1997. Carwars: Trying to make sense of U.S.-Japan trade frictions in the automobile and automobile parts markets. In: Feenstra, R.C. (Ed.), The Effects of U.S. Trade, Protection and Promotion Policies. Chicago, London: University of Chicago Press, 11-32.

McLaren, J., 1999. Supplier relations and the market context: A theory of handshakes. Journal of International Economics 48(1), 121- 138.

McMillan, J., 1996. Why does Japan resist foreign market-opening pressure? In: Bhagwati, J., Hudec, R. (Eds.), Harmonization and Fair Trade. Cambridge: MIT Press, 515-541.

New York Times, 1995. Japan buys more U.S. auto parts. New York Times (National Edition), CXCLIV, no. 50,122, July 14.

Qiu, L. D. , Spencer, B.J., 2000. Keiretsu and Relationship-Specific Investment: Implications for MarketOpening Trade Policy. IBTF working paper 00-04.

Rauch, J.E., 2002. Business and social networks in international trade. Journal of Economic Literature, forthcoming.

Ries, J. C., 1993. Windfall profits and vertical relationships: Who gained in the Japanese auto industry from VERs. Journal of Industrial Economics XLI (3), 259-276.

Rubenstein, J.M., 1990. Japanese motor vehicle producers in the USA: Where and why. Focus, Summer, 711.

Saxonhouse, G.C., 1989. Differentiated products, economies of scale and access to the Japanese market. In: Feenstra, R.C. (Ed.), Trade Policies for International Competitiveness. Chicago, London: University of Chicago Press, 145-174.

Spencer, B. J., Qiu, L.D., 2001. Keiretsu and relationship-specific investment: A barrier to trade? International Economic Review, 42(4), 871-901. 